Rhode Island College

Digital Commons @ RIC

\title{
Instruction Design Towards the Promotion and Integration of Movement in the Visual Arts Classroom
}

Kathryn B. Adams

Rhode Island College

Follow this and additional works at: https://digitalcommons.ric.edu/etd

Part of the Art Education Commons

\section{Recommended Citation}

Adams, Kathryn B., "Instruction Design Towards the Promotion and Integration of Movement in the Visual Arts Classroom" (2014). Master's Theses, Dissertations, Graduate Research and Major Papers Overview. 100.

https://digitalcommons.ric.edu/etd/100

This Thesis is brought to you for free and open access by the Master's Theses, Dissertations, Graduate Research and Major Papers at Digital Commons @ RIC. It has been accepted for inclusion in Master's Theses, Dissertations, Graduate Research and Major Papers Overview by an authorized administrator of Digital Commons @ RIC. For more information, please contact digitalcommons@ric.edu. 
INSTRUCTIONAL DESIGN TOWARDS THE PROMOTION AND INTEGRATION OF MOVEMENT IN THE VISUAL ARTS CLASSROOM

A Thesis Presented

By

Kathryn B. Adams

Approved:

Virginia K. Freyermuth, M.F.A., Ph.D.

Committee Chair

Date

Robert Collins

Committee Member

Date

William Wilson

Committee Member

Date

William Martin

Chair, Department of Art

Date

Earl Simson

Dean, Faculty of Arts and Sciences

Date

Karen Castagno

Interim Dean, Feinstein School of Education and Human Development

Date 


\title{
INSTRUCTIONAL DESIGN TOWARDS THE PROMOTION AND INTEGRATION OF MOVEMENT IN THE VISUAL ARTS CLASSROOM
}

by Kathryn B. Adams

\author{
A Thesis Submitted in Partial Fulfillment \\ of the Requirements for the Master of Arts in Teaching in \\ The Department of Education \\ The Feinstein School of Education
}

Rhode Island College

2014 


\begin{abstract}
My research project focuses on the integration of movement into the visual arts classroom. I explore two questions: "How can the teaching of movement enhance and strengthen learning in Visual Art Education?” and then, “How can I design powerful Visual Art Education learning experiences by incorporating movement"? It is my hope to encourage students in the art classroom to become healthy, life-long learners by engaging the mind and body. This study explores ideas and strategies for integrating the teaching of art with movement for both Elementary and Secondary level students.
\end{abstract}




\section{Acknowledgements}

I would like to thank my family for their continual love, support and patience throughout this process. Thank you to my parents, John and Ann Adams for all that you do for all of us. Thank you to my sister, Cheryl, for always listening and sharing; to my niece, Alexis, for her abundance of movement and conversation; and to my nephew, Mark, for being my personal bodyguard and Marine. I wish to thank all of my teachers and professors who contributed to this path. Thank you to Dawn Bergstrom and Catherine Santosusso for going above and beyond the call of duty. Thank you to my Thesis committee: to my Advisor, Virginia Freyermuth, for her guidance, support and investment in my Master of Arts in Teaching in Art Education and Thesis. To William Wilson, for his continual friendship during my journey within a journey. A huge thank you to Robert (Bob) Collins; it is true when I met him I felt God had sent me an angel. Thank you for your continual help through this long and winding path. Thank you for inspiring me to create again and giving me the ability to move and express myself through art. Thank you for helping me to believe in myself; there are no words to describe what a positive impact that had on my life. I want to thank all of my friends, whether near or far, who again and again, listened to my stories--including all the laughter and the tears. A special thank you to Steve B., for supporting all of my adventures; it is not an easy task. To my Nana, who is not with me in physical body, but continues to love and support me from above, thank you. An enormous wave of love and thanks has to go to my two Yorkshire Terriers, Blue and Pink. They have been to here and back again with me, thank you for giving me such joy. Kathryn B. Adams 
Table of Contents

Thesis Approval Sheet $\ldots \ldots \ldots \ldots \ldots \ldots \ldots \ldots \ldots \ldots \ldots \ldots \ldots \ldots \ldots \ldots$

Title Page $\ldots \ldots \ldots \ldots \ldots \ldots \ldots \ldots \ldots \ldots \ldots \ldots \ldots \ldots \ldots \ldots \ldots \ldots \ldots \ldots \ldots$

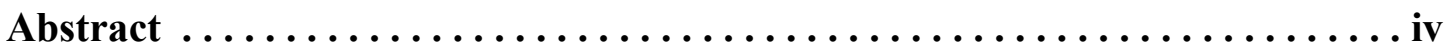

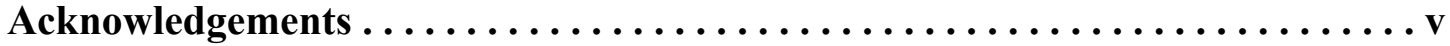

Table of Contents $\ldots \ldots \ldots \ldots \ldots \ldots \ldots \ldots \ldots \ldots \ldots \ldots \ldots \ldots$

List of Figures $\ldots \ldots \ldots \ldots \ldots \ldots \ldots \ldots \ldots \ldots \ldots \ldots \ldots \ldots \ldots \ldots \ldots \ldots$

Chapter 1.

Introduction $\ldots \ldots \ldots \ldots \ldots \ldots \ldots \ldots \ldots \ldots \ldots \ldots \ldots \ldots$

Poem $\ldots \ldots \ldots \ldots \ldots \ldots \ldots \ldots \ldots \ldots \ldots \ldots \ldots \ldots \ldots \ldots$

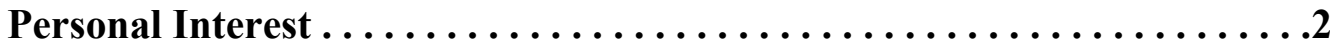

Focus and Research Questions ..................... 5

Chapter 2.

Literature Review .......................... 7

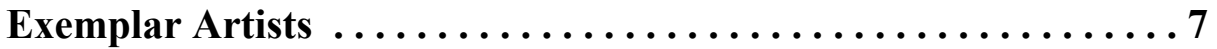

Movement in Education . .................... 12

Learner Centered and Holistic Approaches to Art Education . . . . 16

Somaesthetic and Kinesthetic Learning ............ 20

Chapter 3.

Research Methodology .......................... 25

Qualitative and Quantitative Methodology .............25

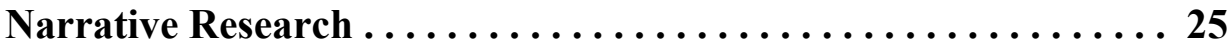

Action-based $\operatorname{Research} \ldots \ldots \ldots \ldots \ldots \ldots \ldots \ldots \ldots \ldots$

Arts-based Research $\ldots \ldots \ldots \ldots \ldots \ldots \ldots \ldots \ldots \ldots \ldots$

Chapter 4.

Initial Planning Process for Movement Enhanced Elementary and Secondary Art Education Lessons $\ldots \ldots \ldots \ldots \ldots \ldots \ldots \ldots \ldots \ldots \ldots \ldots$ 
Chapter 5.

Implementation of Elementary and Secondary Lesson Plans . . . . . . . 34

Elementary Lesson Plans Reflection . . . . . . . . . . . . 35

Secondary Lesson Plans Reflection . . . . . . . . . . 37

Chapter 6.

Recommendations and Summary $\ldots \ldots \ldots \ldots \ldots \ldots \ldots$

Recommendations ......................41

Summary ......................... 42

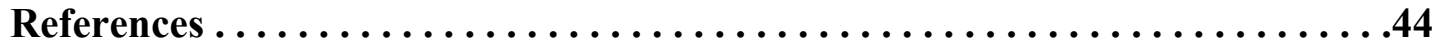

Appendices

Revised and Implemented Art Lessons:

Movement--Enhanced Elementary Art Lessons. . . . . . . . . 47

Movement--Enhanced Secondary Art Lessons. . . . . . . . . 62

Modifications for Special Learners . . . . . . . . . . . . . 78

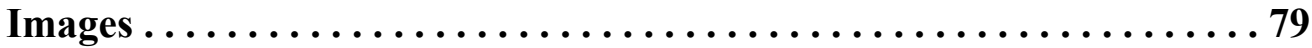




\section{List of Figures}

Figure 1. Sonia Delaunay, $\boldsymbol{R h y t h m , ~ 1 9 3 8 . \ldots \ldots \ldots \ldots \ldots \ldots \ldots \ldots \ldots . . . . . . . . . ~}$

Figure 2. Pablo Picasso, The Guitar Player, 1910............... 8

Figure 3. Wassily Kandinsky, Yellow-Red-Blue, $1925 \ldots \ldots \ldots \ldots \ldots \ldots \ldots$

Figure 4. Willem de Kooning, 1949. . . . . . . . . . . . . . . . 8

Figure 5. Jackson Pollock, Blue Poles, Number 11, 1952............... 9

Figure 6. Heather Hansen, Emptied Gestures, 2012 . . . . . . . . . . . . . . 9

Figure 7. Robert Collins, Entanglement, 2013. . . . . . . . . . . . 10

Figure 8. Robert Collins, Entrapment, 2013. . . . . . . . . . . . 10

Figure 9. Kathryn B. Adams, While You Were Sleeping, \#1, 2012 . . . . . . . . . 12

Figure 10. Kathryn B. Adams, She Sells, 2012 . . . . . . . . . . . . 12

Figure 11. Kathryn B. Adams, The Circle and Square Dance, 2012 . . . . . . . . 12

Figure 12. Action Research Format Graph .................. 27

Figure 13. Kathryn B. Adams, Movement Lesson Idea Mind Maps, 2013. . . . . . . 33 


\title{
Introduction
}

\author{
The child \\ Is made of one hundred. \\ The child has \\ a hundred languages \\ a hundred hands \\ a hundred thoughts \\ a hundred ways of thinking \\ of playing, of speaking. \\ A hundred always a hundred \\ Ways of listening \\ Of marveling, of loving \\ a hundred joys \\ No way. The hundred is there to me...
}

Lori Malaguzzi (translated by Lella Gandini) Founder of the Reggio Emilia Approach (Edwards, Gandidni \& Forman, pg. 3) 


\section{Personal Interest}

Marion North argues that "movement touches directly at a person's primary--even primitive--sensations, feelings and intuition ... and any good teacher, must act as mediator of the various form of expression of his pupils, and also become the investigator by virtue of the disciple of form" (North, 1971, p. xv). The knowledge that children need more movement in their lives and the passion for seeing this topic through has impacted my decision to become a full-time teacher again. "Shortly after his appointment as professor of music at the University of California, Los Angeles, Heifetz (a Russian-born violinist) was asked what had prompted this change of direction in his career. "Violin-playing is a perishable art," said Heifetz solemnly. "It must be passed on as a personal-skill; otherwise it is lost." Then, with a smile, he continued, "I remember my old violin professor in Russia. He said that someday I would be good enough to teach" (Fadiman \& Bernard, 2000, p. 262). I had always considered my design projects “my babies." After recently completing two multi-million dollar residential properties that I felt were my best work to-date, I felt deflated. I reflected on my past and realized that it was time to pass on my personal skills, to invest my knowledge, passion and commitment to the real "babies" -- the lives of children that I could help teach and shape, support and encourage, and watch grow and flourish, in a safe, nurturing environment.

Teaching, designing architectural interiors, and teaching Pilates instruction has made me realize how important movement is for our holistic wellness. In the past I was fortunate to attend Rhode Island College and graduated with my Bachelor of Arts in Secondary 
Education English ('92). Rhode Island College taught me the skills necessary to teach High School English, and I enjoyed inspiring my students to create beautiful literature and to appreciate the art of the written word. After teaching in the Rhode Island school system, I decided to return to college to strengthen my education of art and design. I attended the Rhode Island School of Design. I graduated with a Bachelor of Fine Arts ('95) and a Bachelor of Interior Architecture ('96). I found RISD to be a challenge-I had to learn to think "out-of-the-box." Never before in my life had I been given the freedom to explore, design, and create without "concrete" walls. It was frowned upon if your desk was neat, or if you had a typical night's sleep. It was O.K. if you made a tent out of your desk, pulled an "all-nighter," splattered paint on the floor or made the stairwell into a physics project. My RISD education led me to imagine new possibilities and to gain the skills and confidence necessary to become a successful, professional designer.

While operating my design firm, I started taking Pilates classes. It was during this time that I began to experience periods of euphoria. As Joseph Pilates stated in his Pilates' Return to life through Contrology (1945), "No wonder then that so many persons express such great surprise following their initial experience with Contrology (Pilates) exercises caused by their realization of the resulting sensation of "uplift" (Pilates, 1945, p. 10). My quest for reflective practice made me realize that I couldn't just do Pilates, I had to learn Pilates, and in order to help others feel this sense of euphoria and well being, I had to 
teach Pilates. These experiences have brought me to this path of integrating movement into teaching.

It is my hope to encourage students in the classroom to become healthy, lifelong learners. It is amazing to see a smile light up the face of a student, to witness the moment when they realize that they have accomplished something wonderful by both physically and mentally understanding it. It does not matter if the student is 5 or 85 , if they are K-12 public education students, international apprentices, or those afflicted with rheumatoid arthritis. I have found that movement can be compelling towards a sense of personal accomplishment and growth:

- After an inspiring moment, whether through the making of art or a body movement class, I have witnessed my students hold their bodies taller, have a natural rhythm to their breath, and move to their next task with a sense of pride.

- I have had a 70-year-old male Pilates student beam with joy and say, "Look at this I can touch my toes-I haven't been able to touch my toes since I was seven!”

- I have also had students after a movement and art experience express, "This was the best art class I ever had!" "I felt so free!"... "For the first time in my life I feel like an Artist."

My own pursuit has been to reflect upon and further study the most enlightening parts of my own educational experiences. For over 20 years, I have taught a variety of students, ranging from infants to the elderly: how to draw, paint, sketch, sing; how to read, write, 
and compose the written word; how to research, design, analyze, measure, sculpt, and build; and how to move, stretch, control the body with the mind and the importance of breath. I would like to compile these integral parts of my own journey as a teacher and lifelong learner into a program of study through which my students could relish the importance of movement and art.

\section{Focus and Research Questions}

My research project focuses on the integration of movement into the visual arts classroom. I came across this idea during my practicum experience at the High School level. I had designed a unit for the students to learn about the field of interior design. Initially, we were learning about scale and measurements. I was having difficulty getting the students motivated to contribute to the class discussion, or even to hold the measuring tape. The lesson was going downhill quickly. I had a brainstorm. Instead of using the measuring tape, what if I had the students pretend to be parts of a room? I asked the students to stand up, which they did. I then asked a student, "What does your bedroom look like?" While she explained, I had the students "be" a window, a wall, a chair, the fireplace; and I had one student even lay down on the floor for the bed. The transformation was magical. The class became animated and started discussing volumes, spaces, and what objects looked like. "You have a fireplace in your room?" asked one student. Another student chimed in with "I only have room for a bed," and another, "I don't even have a bed!" There was lots of laughter. By physically moving around the 
room pretending to be inanimate objects, the class began to engage each other in new ways that I had not previously witnessed.

That moment and others like it are behind the direction of my research project. I was so excited about what had happened in the classroom that day that I had to ask myself, "Can the teaching of movement enhance and strengthen learning in Visual Art Education?" and then, "How could I design and integrate powerful Visual Art Education learning experiences by incorporating movement?"

The focus and goal of this thesis is to promote movement in Elementary and Secondary visual art classrooms. Through the development and implementation of meaningful art lessons that incorporate movement in Art Education, I aim to show that, when mentally and physically possible, movement can be used to serve as a catalyst for students to communicate through the visual language of their own works of art. 


\section{Chapter 2.}

\section{Literature Review}

In the following section I will introduce and explain a variety of topics that support this Thesis project. These include Exemplar Artists who incorporate movement into their work, Movement in Education (Arts-based and non-Arts based), Learner-Centered and Holistic approaches to Art Education, as well as Somaesthetic and Kinesthetic Learning.

\section{Exemplar Artists who incorporate movement into their work}

There are a number of visual artists who incorporate movement into their work. I chose the following Exemplar artists for two distinct reasons. One, for artists who portray visual movement in their work, and two, for artists who use bold, physical movements to create art. I wanted the students to become familiar with both types. My aim was to have the students to understand the importance that art is more than just a product; the process of mark--making has strong merit on its own.

Sonia Delaunay was one of the first artists known for visual movement. She is known both for her fascination with color and using it to create the appearance of movement. Her strategic use of color in abstract geometric forms leads the viewer's eyes to move throughout the canvas. Her art is not limited to only paintings; she is also known for her furniture, fabrics, wall coverings, stage set and clothing designs; virtually moving through all design media; infusing movement into her art (Grosenick, 2001, p. 96).

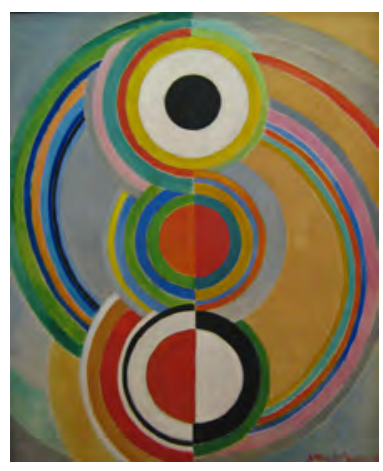

Figure 1. Sonia Delaunay, Rhythm, 1938 (http://en.wikipedia.org/wiki /Sonia_Delaunay)

The Cubists, Picasso and Cezanne, also portrayed visual movement in their art. They showcased movement through their use of radically changing perspectives on an object and the theory that your mind also holds a memory of an object. Not only do they allow 


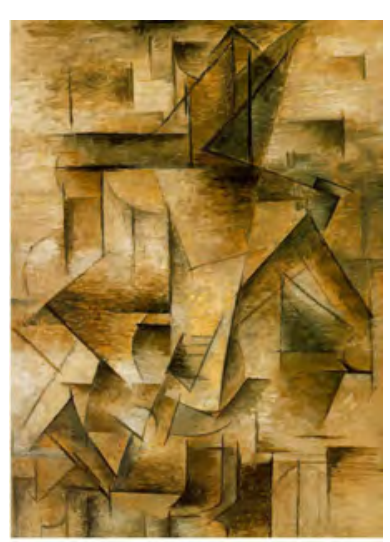

Figure 2. Pablo Picasso, The Guitar Player, 1910

http://www.artchive.com/view er/z.html the viewer to observe their canvas and see many points of shifting planes at once, they entice the viewer to physically wander around the canvas yet again changing their viewpoint. Gardner states of Picasso, "Clearly, Picasso had sufficient manual dexterity to draw copiously and competently ... In terms of multiple intelligences theory, Picasso's precocity was most striking in the visual-spatial, body-kinesthetic, and interpersonal areas" (Gardner, 1993, p. 141).

Kandinsky is known as a Master for his illusion of visual movement. He created a unique personal shape vocabulary to manufacture the very beautiful, but tightly composed paintings that allowed the shapes, lines and marks to float off the canvas while creating a sense of space in his work. To achieve his explosive use of space, Kandinsky kept to a grid and used

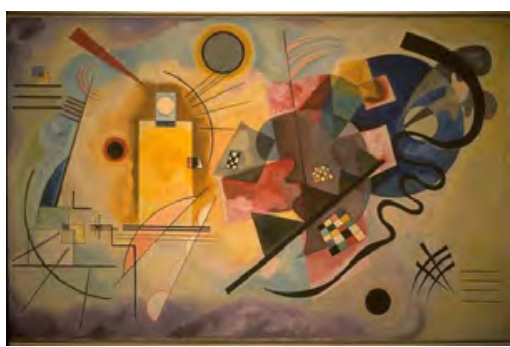

Figure 3. Wassily Kandinsky, YellowRed-Blue, 1925 o/c Musee Nationale d'Art Moderne (Centre Pompidou), Paris abstraction and formal elements such as color balance, vertical, horizontal and diagonal lines to portray a strong and vibrant sense of movement (R. Collins, personal communication, February 12, 2014).

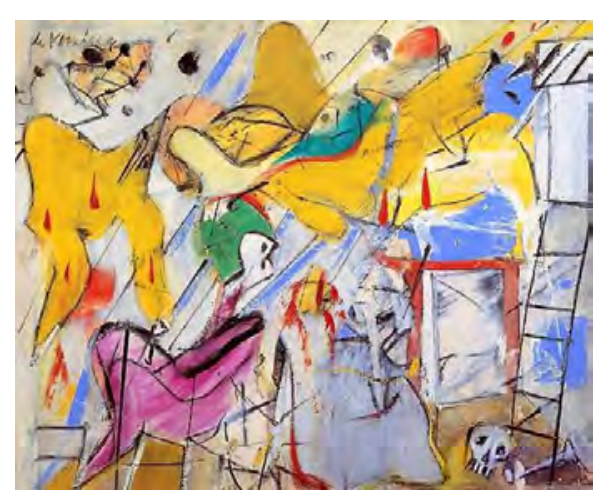

Figure 4. William de Kooning, 1949, G.m Dagli Orto/DeA Picture Library
Another Visual Artist whose works exude visual movement is Willem de Kooning, who said of his own work, "The figure is nothing unless you twist it around like a strange miracle." Roberta Smith stated in a 2011 Article for Pace Gallery that "de Kooning saw the figure as a rubbery, infinitely 
malleable subject perfectly suited to the malleable substance of paint and also to his conception of the painting process as one of unending, never-resolved flux and instability" (Smith, 2011, n.p.).

Abstract Expressionist Jackson Pollock's is known for his bold, physical movements to create his art. Pollock's process of pouring and dripping paint is thought to be one of the origins of so-called "action painting"

(Aimone, 2009, p. 25). With this technique,

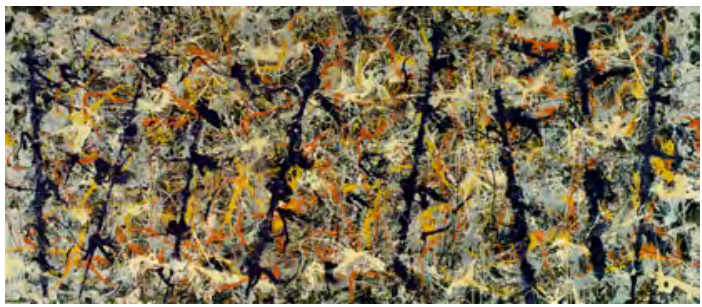

Figure 5. Jackson Pollock, Blue Poles, Number 11, 1952

Pollock was able to achieve a more

immediate means of creating art, the paint now literally flowing from his chosen tool onto the canvas. By defying the convention of painting on an upright surface, he added a new dimension by being able to view and apply paint to his canvases from all directions (Aimone, 2009, p. 26). He used the process of movement, physical energy and mark making. The structures of his compositions hold together all of the energy of the marks and shapes. He is an exemplary artist whose work can be used as a great example for movement in a classroom. For example, many teachers use Pollock's method by having their students paint left to right using a count of 8 . This creates exciting movement across the canvas, and allows the students to experience both the process and product ( $R$. Collins, personal communication, February 12, 2014).

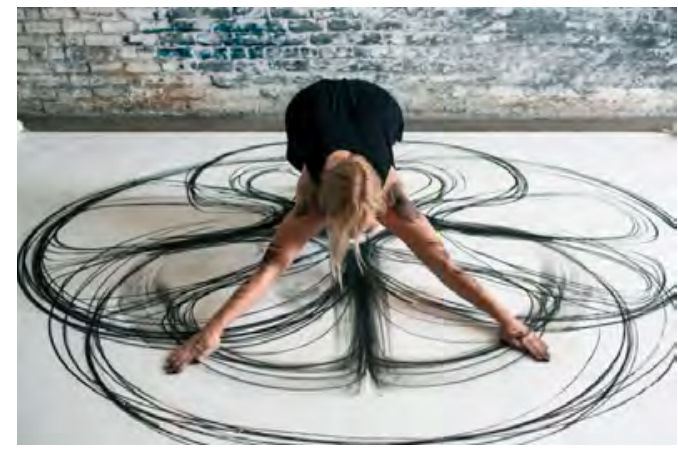

Figure 6. Heather Hansen, Emptied Gestures, 2012 http://youtu.be/mnnUpxAuWUI
Contemporary artist Heather Hansen explicitly emphasizes the experience of using physical body movements to create art. She interprets her dance moves onto large paper canvases using her body and charcoal. (http://youtu.be/mnnUpxAuWUI). The spectator sees movement in her art, but also 
becomes aware of the athleticism involved in making a visual artwork. One could say that her work represents the process of making visual artwork, a process of which many spectators are unaware when they look at an apparently static painting or sculpture. I did have the opportunity to show this powerful online You-tube video to my Secondary students. Her process mesmerized them. Many of the students asked if they, too, could create these large-scale works. Due to the scheduling and the curriculum needs, I could not implement this particular avenue of study. In the future, I would have students put on paper suits (hopefully donated by local businesses) and compose these amazing large charcoal floor works using sweeping body movements. I believe they would be energizing, captivating, and enlightening.

Robert Collins is a Contemporary Abstract Artist and Art Educator. His work integrates movement, color, shape, form, line, and mark making to create dynamic works of art.

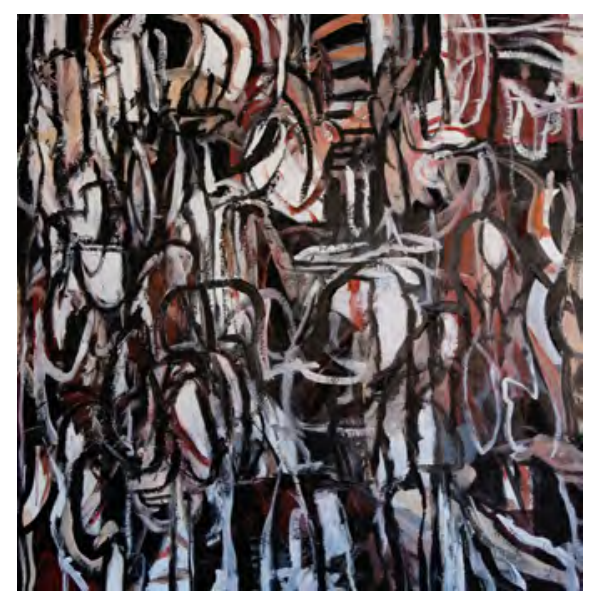

Figure 7. Robert Collins, Entanglement, Photo courtesy of Artist, 2013.

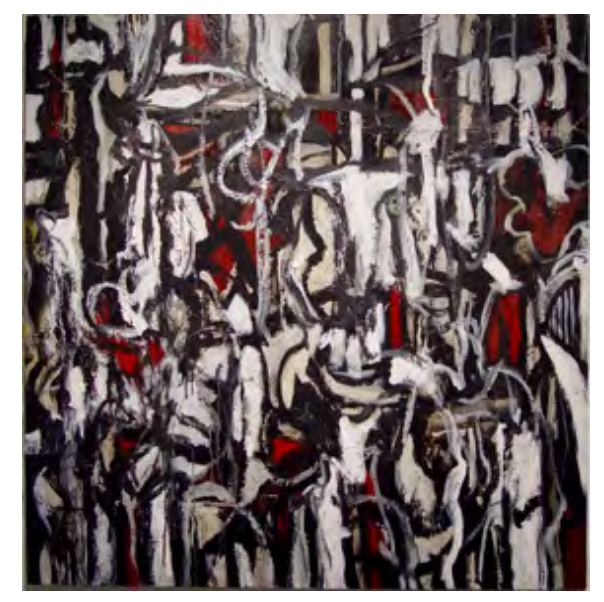

Figure 8. Robert Collins, Entrapment, Photo courtesy of Artist, 2013.

In a statement of his own work, Robert Collins states:

I believe everyone can make marks, doodles, shapes, lines, and explore materials to the fullest. In my work, I do several exercises dealing with shape, line and movement that allow me to stretch my shape vocabulary 
and mark making skills which then need to be composed into the final piece of work.

I feel it is important to allow the maximum amount of creativity to be reached in order for the variety of shapes, marks, etc... to be produced. Whether using movement, dance, gestural marks, music or physical exercise - keeping this level of intent and enthusiasm is very important in today's art making! (For all ages)

My art comes out of resolving all this information and shapes that I create into a final composition. I use various exercises and techniques to create 2-dimensional flat shapes. The arrangement and compositions of the shapes becomes my art. I need to control and harness all the energetic shapes/lines/movements, etc... to a more formal composition. The process of shape development causes the final design and composition to occur.

I enjoy the use of a grid design to stabilize my paintings into a more geometric and unified design. The grid aids in the placement and organization of shapes, lines, gestural marks, etc... The grid can be used as a shape-creating device and can cause a unique composition to appear. This allows the controlled and uncontrolled parts of the brain to work together in the same piece of art. Grids allow verticals, horizontals, and diagonals to come into play with my compositions (R. Collins, personal communication, February 12, 2014).

In order to fulfill a graduation requirement, I enrolled in a 2-D Synthesis class at Rhode Island College with Robert Collins. He would unravel large sheets of paper, put on music, and draw and paint with such energy. It was magnetic. I became an instant groupie and continued to take other classes. The experience of working with him and learning how to relax my mind and body, to create marks and to capture the essence of movement into art inspired my own art making as well as my lesson planning. I wanted to give my students the ability to embody this energy, to feel inspired and less restricted in order to create their own art. 
The following images are from some of my own personal movement and expression pieces composed under the guidance of Professor Collins.

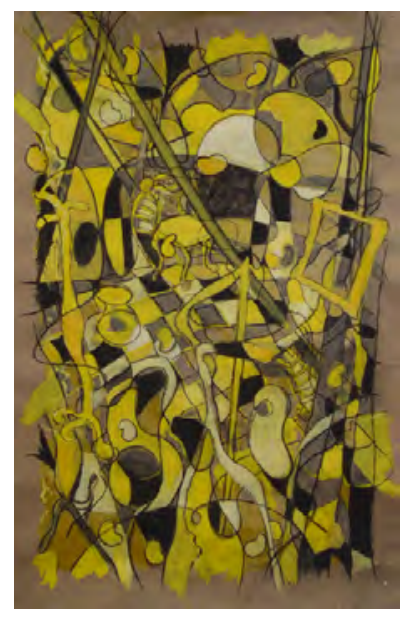

Figure 9. Kathryn B. Adams, While You Were Sleeping \#1. Photo courtesy of Robert Collins.

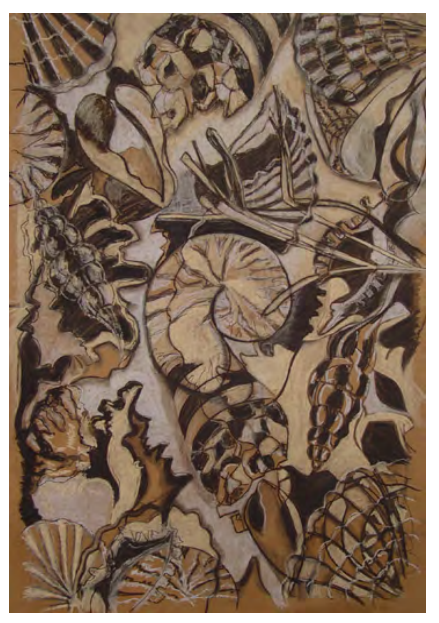

Figure 10. Kathryn B. Adams, She Sells. Photo courtesy of Robert Collins.

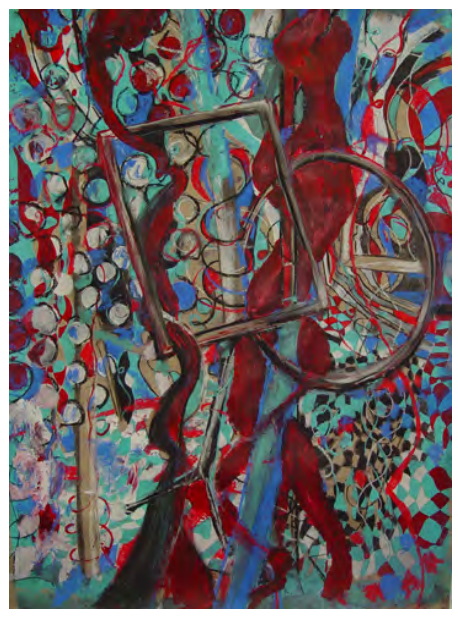

Figure 11. Kathryn B. Adams, The Circle And Square Dance. Photo courtesy of Robert Collins.

\section{Movement in Education}

In this section I will explore educators who design curriculum combining visual art and movement. They have based their curriculum on their own daily experiences as well as on research.

Accomplished educator, multi-disciplinary artist, and author, Cyndie Belen-Berthezene received the Greene Grant from The Maxine Greene Foundation, Inc., in June 2007 for a Pre-K-First Grade, privately funded, New York City arts program, The Time In Children's Arts Initiative at HiArt!:

“...This year-long, weekly half-day arts (immersion program) introduces students from underserved schools to a full range of arts-based experiences - music, movement, hands-on and visual arts, literature and film. The young students learn to express themselves artistically as individuals and develop the sustained focus needed to work on a single 
project over an extended period of time."

(http://www.maxinegreene.org/2007_hiart.html)

The HiArt program studio day consists of:

Core work - a musical masterpiece - dramatically, visually and kinesthetically presented ... Children use the music as a source of inspiration, fleshing it out in their own mixed-media artworks that continue to evolve throughout the summer. The second part of the "typical" morning might be spent at museums or on gallery hops, doing large-scale outdoor art activities, or completing studio art projects related to an exhibition we've visited or will visit. As they immerse themselves in their art projects -- developing their personal artistic vision and skills -children become actively, rather than passively, involved with the core work."..."We dance on sparkling floors and sully them daily with masses of paint, glitter and every conceivable art supply imaginable." (http://www.hiartkids.com/index.htm.)

Mark DeGarmo operates Dynamic Forms, Inc., another organization based out of New York City. His program is committed to "changing lives by making the arts and dance a permanent part of an improved public education system" (http://markdegarmoarts.org/schools/evaluation_findings/). Dynamic Forms programs incorporate movement, improvisation, and non-verbal learning through Art. Since 2008, they have been conducting research on the impact of these programs in the classroom. Some of the findings are: "students displayed increased academic success in literacy and math, increased kinesthetic skills, greater emotional maturity, and developed more positive ways to act in the world than their peers in the control group without the benefit of the MDDF program" (http://markdegarmoarts.org/schools/evaluation_findings/). These programs serve as inspiration for the sustainment of movement in art.

Some K-12 non-arts educators integrate movement into their classroom. For example, Michel Plemmons, a high school teacher in Kent, Washington realized that students needed an outlet for their "wiggles." She makes tire swings for tapping feet. In North Carolina, Scott Ertl lets students ride on exercise bikes while reading; he says, "Because they love being active, they find that the movement allows them to have more fun 
reading. Many students previously thought reading was boring or too hard, but now they see reading can be fascinating and fun" (Education World, 2013, n.p). Similarly, elementary educator Gwyn Ann Raczkowski, at Brittin Elementary School (Department of Defense Education Activity stateside school system) of Fort Stewart, Georgia allows her students to use stability balls, and to sit on the floor, to help her students stay active and focused. She feels students have better concentration if given Yoga exercises before testing. Judy Jenkins, a Fifth grade teacher at Captain Isaac Paine Elementary School in Foster, Rhode Island, starts her classroom with yoga movements. I have had the pleasure of teaching Art to her class, and I find that as a whole, the students are very calm, respectful and engaging. Although there are varying opinions about teaching yoga in public schools, I feel that an educator could remove the word "Yoga" and focus on the health benefits of daily mindful breathing, moving and stretching exercises.

A number of teachers at Captain Isaac Paine Elementary School integrate movement into their curriculum; Becky Howarth takes her $3^{\text {rd }}$ grade students outside everyday. She is a proponent of "play for play" and believes kids need to move. Sue Krikstone plays movement DVD's when students do not have outdoor recess. Margie Jones, the Music teacher, moves with the students while they are marching and dancing, plays musical chairs and has incorporated a "still" lesson for the students to appreciate the importance of both complete stillness as well as active movement. The art teacher, Dawn Bergstrom, has students work outside in the courtyard, and organizes nature walks to incorporate movement. Catherine Santosuosso, the Physical Education teacher, continually monitors the progress of the students while working closely with teachers to integrate physical activity into a variety of new and exciting ways.

In 2007, The New York City Department of Education funded a Kinetic education program to provide Arts Education to the public schools. In 2007, The New York City Department of Education funded a Kinetic education program to provide Arts Education to the public schools. The Center for Kinesthetic Education "offers programs for 
classroom and dance educators interested in using movement and dance to develop students' movement skills, dance-making ability and artistic expression. (http://wellnesscke.net/k12.htm) Dr. Martha Eddy from the CKE learning institute wrote Rationales, Guidelines, and Resources to get schools moving. She suggests why kinetic movement should be integrated in the classroom:

WHY move: 1. Our bodies are designed to move, 2. Some people think best when they are moving, 3 . To engage diverse types of learners fully kinesthetic learners or sleepy ones, 4 . To deepen understanding, 5. To experience a subject from a new perspective, using kinesthetic intelligence, 6 . To develop creativity, 7. To foster community, 8. To rest, recuperate and refocus, 9. To invigorate the body-exercise for health, and 10.To have fun!

(http://www.WellnessCKE.net/cr.htm, (2010), Calendars and Resources/K-12 Page)

Students at all age levels, with various needs and abilities, could potentially benefit from this study. As Twyla Tharp states, "Movement stimulates our brains in ways we don't appreciate" (Tharp, 2003, p. 24). If, in any way, movement can make students feel more confident and possibly assist learners' skills to think critically, to move their bodies, and to create life-long learners, then this subject will make their education more personally meaningful, in my opinion.

Integrating movement into the art classroom is important. Many experts in the field have concluded that movement is a vehicle to help both children and adults to enhance their growth and development (North, 1971, p. v). In order to create critical thinkers and successful entrepreneurs, we must provide a strong educational background infused and enriched with performance-based art as well as visual art. During my own public school education, I was able to make art, play musical instruments, sing in chorus, act in drama, and work with artists in-residence. Without these artistic avenues, I would not be the person I am today. 
Integrating movement is one way I hope will help students and teachers feel more creative, calmer, and clearer in all aspects of their lives, not just during art class. The literature I have presented remains consistent on the subject of the importance of movement and education. The insights gained offer fresh ideas to improve our American education classrooms. If we are to help children keep their curiosity and creativity, we must stimulate our students in a variety of ways, in my opinion. The founders and followers of all these programs presented share the belief that by integrating movement into education process, the students learn to better express themselves. I agree with this vision. Throughout my research process I have not found any evidence to the contrary.

\section{Learner-Centered and Holistic Approaches to Art Education}

There are many different philosophical approaches to Art Education. I find LearnerCentered and Holistic approaches are most relevant to this study. Dr. Cheryl Williams has instilled in each of her students the knowledge that the ultimate goal of every educator should be to provide "all children with appropriate, safe, and meaningful art experiences" (Williams, 2012, class lecture). Like any aspiring teacher of the arts, it is important to consider my own philosophy of art education as a foundation for my art teaching. My concerns encompass primarily the Child, the Art content, and the value it brings to society. Philosophically I must approach the subject with core valuable questions. I have to ask myself, "What do I envision as high quality art teaching? What is the meaning evoked by the children's words, images, and ideas? And at the end of the day, the lesson, the semester, or the year--what critical thinking occurred and how did the children reflect and grow based on their learning about and through the subject matter?"

I believe, as Art Educators, we need to give children the space and freedom to create and imagine, and the ability to spread their wings and grow. As Albert Einstein stated, "Imagination is more important than knowledge." As an educator my wish is to help my students to actualize their fullest potential and to keep their curiosity alive. 
In Approaches to Art in Education, Laura Chapman discusses the role of John Dewey, who was the pioneer of this movement and so redefined the nature of art education. "In Dewey's view, children should be treated as active learners whose creative energies center on themselves and their world" (Chapman, 1978, p.11). As an art educator I am the facilitator to bring out the creativity of each student. If I positively influence a student, that student could potentially have a positive impact on the world.

The development and growth of a child consists of an intricate, holistic process. As educators we need to understand that all aspects of a child's life including cognitive, emotional/moral, social, language, physical, and aesthetic development play a crucial role in their learning and growth. It does not matter if a child is considered to be an artist. Most children pass through the same phases of artistic development, observable from the marks they make. We witness these stages of progress in the child's creation of art. These stages start at approximately 2 years and generally progress to age 17 . One theory of Artistic Development categorizes the stages as follows: Mark-Making (ages 2-4), Early Symbol Making (ages 4-7), Symbol Making (ages 7-9), Emerging Expertise (ages 9-11), Artistic Challenges (ages 11-13), Artistic Thinking (ages14-17) and Adult (ages 18+) (Simson, et. al, 1997). Starting with the sheer delight of using their bodies to make a mark, children generally progress through childhood to be able to represent objects realistically. As they become young adults they may then make a conscious choice to distort an image to create artwork that represents their individual style.

As art educators we work on developing the "whole" child. Feldman states, "When teaching art we encounter students in the fullness of their being, so we cannot be indifferent to the wholeness of their development. 'Wholeness' is linguistically related to "hale," and "health," which suggests that the cognitive and moral dimensions of a subject should not be separated from teaching the subject. That would be true of any educational philosophy "worthy of the name" (Feldman, 1996, pp. 97-98). The incorporation of 
movement into the classroom does not stray from this ideal philosophy; it improves the very fabric of a healthy child's life, in my opinion. As part of this process, it is also my mission to ensure that this creativity is conducted in an atmosphere of mutual respect and toleration of diverse opinions, a safe environment, so that an open discussion of art and self-expression can take place. Finally, since various individuals and groups from different cultural frameworks create art, beliefs and practices, it is vital that art be presented within a multicultural context.

Peter London (2006) discusses holistic education and holism as "a dynamic phenomenon, the being who is actively engaged in creating their life moment by moment, and their art, project by project. It is therefore addressing and ultimately integrating mind, body, and spirit" (London, 2006, p. 8). I strive to teach art by promoting mindful, intellectual art making. My methods include principles and elements of design, such as color theory, pattern, line, rhythm, drawing, painting and sculpting. I have incorporated the body into the mindful making of artwork that focuses on the senses--closing your eyes and drawing to music, making gesture drawings from small to large range, and using body movements themselves to make small-to-large marks. It seems to me that many educators have ignored or under-used the potential of the body in art making. The possibilities seem endless, yet in my opinion, not put into practice as much as seems desirable for a Holistic Art Education practice.

As research has established, this topic is important for all teachers, not only art educators. For example, in 2008, Dr. Mark Rapport, the supervisor of the study and Professor of Psychology at the University of Central Florida in Orlando, conducted a study finding that children actually need to move to focus during a complicated mental task (Bright, 2013). "Teaching requires something more than stimulating a response. It is necessary to provide stimulating opportunity for formulation, for building a framework and a structure, as it is to allow individual contribution and invention by the pupil" (North, 1971, p. xiii). I have developed a framework towards designing art lessons that defines, 
features, and focuses on the connections between art education as an intellectual and emotional pursuit that is strengthened and enriched through engagement of the body and movement. It is invaluable for all teachers and students to move, stretch, to be inspired, to feel creative and to be spontaneous.

I understand that this holistic educational perspective is not without controversy and the misunderstanding that religion is being introduced into the curriculum. "But after decades of headlines about "a generation at risk": we dare to do so: the void of spiritual guidance for teenagers is a contributing factor in the self-destructive and violent behavior plaguing our nation" (Kessler, 2001, p. 108). My approach is to educate the whole child by also acknowledging my belief that each child has within them an inner light, "a spirit." The Oxford Dictionary of Word Histories defines spirit as: 'from Latin spiritus 'breath, spirit', from spirare "breathe"” (Chantrell, 2002, p. 478). Spirit is also defined as "an immaterial force within a human being thought to give the body life, energy, and power." (http://www.merriam-webster.com/thesaurus/spirit) I believe education requires more than just stimulating the mind. Rachael Kessler, the author of Soul of Students, Soul of Teachers, states: "Honoring the soul in education means attending to the spiritual development of students. The body of the child will not grow if it is not fed; the mind will not flourish unless it is stimulated and guided. And the spirit will suffer if it is not nurtured" (Kessler, 2001, p. 108). To me, art making encompasses the mind, the body, and the spirit; it is more than a product--it is an entire experiential process. The making of art requires a process that reveals itself over time. In order to create, an artist must imagine, translate, respond, revise, adjust and reflect. There is a continual movement of both mind and physical activity throughout the artistic process. The artist amasses not only works of art but acquires a collection of ever-changing life experiences.

During my Elementary Practicum, I overheard one student tell another "Making art makes me feel like giving gifts" (Anonymous student, 2013). "Very often children "make art" as gifts for their loved ones. What they are giving is the gift of their creative spirit" 
(Conte, 2001, p.82). As educators we can "allow students to give their gifts to the world through school and community service, through creative expression, or through academic or athletic achievement" (Kessler, 2001, p. 112). The gift I want my students to take with them long after art classes are over is that embodied learning experiences combined with feelings are powerful and memorable. The feelings of joy and the power of physical movement are the lasting gifts of movement itself. Even if one were to live to a be one hundred, and have lost the ability to move, I hope the memory of creating a work of art would keep the sprit alive and the mind at peace, with the remembered sensation of what the body had created.

\section{Somaesthetics and Kinesthetic Learning}

I also find Somaesthetic and Kinesthetic learning relevant to this project.

In 2001, Eric Jensen wrote Art with the Brain in Mind. He states that some of the research on the correlation between recreational activity and cognition "suggest that physical education is responsible for improved self-concept, enhanced academics, and enjoying school more" (pp. 92 - 93). I wish to include the concepts and theories of Richard Schusterman, a follower of John Dewey. His theoretical research on Somaesthetics, the discipline of "actually engaging in programs of disciplined, reflective, corporeal practice aimed at somatic self-improvement" resonates with this work; focusing on aesthetic, kinesthetic as well as holistic practice:

"In visual arts, somaesthetics has been used to explain not only how artists use their bodies in making artworks but also how observers deploy themselves somatically to perceive such works. Many works of visual art (whether paintings, sculptures, photographs, or installations) consciously presuppose and play with the viewers' somatic standpoint, so that the soma can be powerfully thematized in a work without a body being visually represented in it" (Schusterman). The body (with its multiple senses and movement through space) likewise plays a formative role in architectural design and experience. 
Schusterman believes that:

"No technological invention of virtual reality will negate the body's centrality as the focus of affective, perceptual experience through which we experience and engage the world. Second, that cultivating better skills of body consciousness can provide us with enhanced powers of concentration to help us overcome problems of distraction and stress caused by the new media's superabundance of information and stimulation" (Somaesthetics: Thinking through the body and designing for interactive experience, 2013, n.p.).

The latter, the specific practices of somaesthetic training to which Shusterman regularly refers, includes breathing, bodily attunement, and mindfulness. Somaesthetics serves as another framework to help us understand the value of increased creativity and consciousness through movement and art. From my observations to date in schools, I have seen many tense, stressed, and angry children. I have had students cry when they felt they drew the wrong line, cry when they felt their project did not come out "right," crumple artwork, and yell in frustration; and I have also witnessed a student make an angry mark on another student's artwork because he felt it was better than his own. Zephryn Conte, author of The Gift of the Arts, describes the experiences of Tara, an abused, abandoned and partially deaf student. For a number of weeks during a "movement unit" Tara would not move her body or participate in any activities, she chose to sit and write in her journal (Conte, 2001, p.79).

As the months followed Tara slowly became more active with the class. She felt safer, to a point where she was able to express her emotions within the group. Her body softened and her movements became more fluid. Her hearing seemed to improve as a result of some of the music listening activities we practiced. A child who had been angry and withdrawn was now more trusting and open (Conte, 2001, p. 82).

Tara wrote in her journal: "I know things about myself I never knew before. The best was the special studies, I could really feel it, my body never knew how to feel space before. ..."(Conte, 2001, p. 89). I hope that by encouraging movement, along with a 
practice of being mindful of one's breath, one's body, and a respect of self, that the students will gain a stronger, positive sense of respect for themselves and others.

I wish to extend the interest beyond cultivation of the mind toward the intelligence of the physical body itself. In Multiple intelligences: The theory in practice, Howard Gardner proposed seven intelligences. They are linguistic, logical-mathematical, spatial, bodily kinesthetic, musical, interpersonal and intrapersonal (Gardner, 1993, pp. 189-190). The (verbal)/linguistic learners learn best through the written and spoken word; logicalmathematical (visual learners) learn best work better with pictures and charts--using images and watching demonstrations; bodily-kinesthetic learners learn most effectively from movement-based or motion orientated activities (Chen, 2009, n.p.), musical/auditory/aural learners learn best through from oral instruction, verbal commands-sound and music; as well as interpersonal, "the ability to understand people" (Gardner, 1993, p. 190), and intrapersonal "the capacity to form a veridical model of oneself, and to be able to use that model to operate effectively in life" learners (Gardner, p. 190). In 1999, Gardner wrote of an additional three intelligences, naturalist, spiritual and existential intelligence (Gardner, 1999, p. 15).

Movement honors the kinesthetic learner, those "individuals who demonstrate excellence in area of sports, dancing, hands-on tasks, physical activities and motor skills" (Chen, 2009, n.p.). As a kinesthetic learner it is difficult to remain quiet and still in a classroom. I believe not only am I a visual learner but a kinesthetic learner as well. In elementary school, I was continually made to sit in the corner and face the wall. I could not sit still for any length of time. I would peek into my desk, rearrange the contents, write notes, learn forward and whisper in a friends ear, then turn around to talk to someone else. My teachers would tell me I talked too much, hence, the banishment to the corner. What torture! If I had been given another approach to my task, I'm sure I would have been more successful. I laughed out loud when I read a quote excerpted from Chenfield in Can Adding Movement to Learning Improve the Classroom: 
One day, early in the school year, at 11:30 in the morning, a child went to the closet, took his jacket and bag, and started for the door. Stopping him, the teacher gently asked him where he was going.

"Home," he said.

"Honey," she told him, "You don't go home now. You're in $1^{\text {st }}$ grade. You get to stay all day."

Placing his hands on his hips, with wide eyes, the boy asked, "Well, who the hell signed me up for this? (Chenfeld, 1992, p.89).

As Victor Lowenfeld wrote, "If we really expect to develop an enquiring mind in a child, one that is eager to tackle the problems of today, a mind that is flexible, inquisitive, and seeks for solutions in unusual ways, then the attention we have paid to the so called basic learning areas may be ill-placed" (Lowenfeld \& Brittain, 1987, p. 53). I believe we must continually strive to work together to give our students the most current, excellent and appropriate education that sufficiently meets their intellectual, physical and spiritual needs. Our bodies are designed to move. The word "Move" is from Old French movier, from Latin movere. The main semantic strands are: 'proceed' (e.g.) he moved awkwardly along the narrow passageway), 'cause to feel emotion' (e.g. moved me to tears), and 'cause to act' " (Chantrell, 2002, p. 334). To move, then, is an integral part of our beings: It is how we propel ourselves through the world. It is the how we display our emotions, for laughing, crying, smiling, hugging, and screaming all involve movement. It is how we bodily internalize these emotions that make us feel and act the way we do. Do we project anger or jealousy in the form of sulking or slamming a door? Do we collapse our posture because we feel insignificant, inferior or are trying to remain invisible? Does our posture not convey our confidence? Or do we open our arms to hug someone or press our bodies against another we love dearly? Even facial expressions and speaking are forms of movement.

There is an ever-increasing amount of research on movement and its effects on the quality of education. In Teaching with the Brain in mind, $2^{\text {nd }}$ edition, Eric Jensen states (2005) that the research on increasing exercise shows "increased cognition, better 
memory, and reduced likelihood of depression" (Kempermann, 2002). Researcher Terrence Dwyer is one of many who have conducted multiple studies suggesting that exercise supports success in school. His research found that exercise improves classroom behavior and academic performance (Dwyer, Sallis, Blizzard, Lazarus, \& Dean, 2001). (http://www.ascd.org/publications/books/104013/chapters/Movement-andLearning.aspx). I believe that incorporating more movement into the classroom will produce positive results. I believe this because I have experienced it myself. When I cannot concentrate on a task because I have been working on it too long, I need to get up and move around. Only then can I tackle the project at hand with a renewed sense of clarity. I also witnessed the positive reactions from my students after their movement lessons, which will be discussed further in the Chapter on reflections. 


\section{Chapter 3.}

\section{Research Methodology}

\section{Quantitative and Qualitative Research Methodology}

This study focuses on my progress of designing art lessons that incorporate movement for Elementary and Secondary art classrooms. I choose between the two main research approaches--Quantitative and Qualitative; as well as Narrative, Action Research and Arts-Based Research in order to best investigate this topic. Quantitative Research typically removes the investigator from the investigation (Smith, 1983), measures a large sample of the population, collects statistical data and recommends a conclusive course of action (http://www.snapsurveys.com/qualitative-quantitative-research/). The chart below, from The American Journal of Occupational Therapy (Krefting, 1991, p. 214), emphasizes the differences between Qualitative and Quantitative Approaches:

\begin{tabular}{|l|l|l|}
\hline \multicolumn{1}{|c|}{ Criterion } & \multicolumn{1}{|c|}{ Qualitative Approach } & \multicolumn{1}{|c|}{ Quantitative Approach } \\
\hline Truth value & Credibility & Internal Validity \\
\hline Applicability & Transferability & External Validity \\
\hline Consistency & Dependability & Reliability \\
\hline Neutrality & Confirmability & Objectivity \\
\hline
\end{tabular}

Qualitative research "emphasizes the importance of looking at variables in the natural setting in which they are found" (Key, 1997, p. 1). Therefore, I chose to rely upon Qualitative Methodology. There are four Qualitative approaches: Narrative, Ethnographic, Phenomenological, and Case Study.

\section{Narrative Research}

This study utilizes Narrative Research. In an attempt to distinguish the research in this study further Action Research and Arts-Based Research were also used. These particular 
methodologies were utilized not because there was one stance better than the others, only that they all better in doing different things (Saunders et al., 2003). The Narrative approaches to Educational Research by Sikes and Gale states:

Put as simply as 'an account of something,' it is clear that narrative is unavoidable; it's everywhere, and is fundamental to human understanding, communication and social interaction. Indeed, somewhat playfully, it has been suggested that there is a case for revising the term homo sapiens to 'homo fabulans - the tellers and interpreters of narrative' (Currie, 1998, p. 2). For narrative is what we do. We use it to make sense of the world as we perceive and experience it and we use it to tell other people what we have discovered and about how the world, or more specifically how aspects of it, are for us. This component, for example, is a narrative account of our understandings of narrative approaches to educational research. Within the social sciences though, 'narrative' and, specifically in the context of this component, 'narrative research' has come to have particular meanings; meanings that carry or are attributed with, particular value, ethical, ontological and epistemological positions. We should note that, as is the case with most research approaches, there has been much disagreement and debate about definitions, meanings and practices (see for example, Riessmann, 1993). Narrative is a contested, complex, transitional and developing field (see Chase, 2005) and readers should be aware that this component makes no claims to be definitive (see Rudrum, 2005, and Porter Abbott, 2002 for contrasting, yet complementary examples of discussion)." (http://www.edu.plymouth.ac.uk/resined/narrative/narrativehome.htm).

I am a storyteller by nature, so this approach best matches my study because I aim to understand and tell the story of what I have observed of my own teaching in my 
student teaching experiences. I will discuss my view through my own story, be it a positive or negative effect, upon integrating movement into the classroom.

\section{Action Research}

I also used Action Research. In a recent Ted talk, Bill Gates posed the question, "How do you make education better?" We as educators need to continually ask ourselves this question. Action-based research lends itself directly to this question. Educators identify areas that need to be addressed, plan and design lessons for their students within their curriculum formats. Lessons are then implemented. The students' behavior, progress, and outcomes are evaluated and assessed. Just as action research is continually typically carried out within a circular, dynamic format; the lessons are then reflected upon and modified in order to obtain an even greater result. Then the process begins again--a continual evolution of reflection and implementation. I continually utilized this process throughout my study.

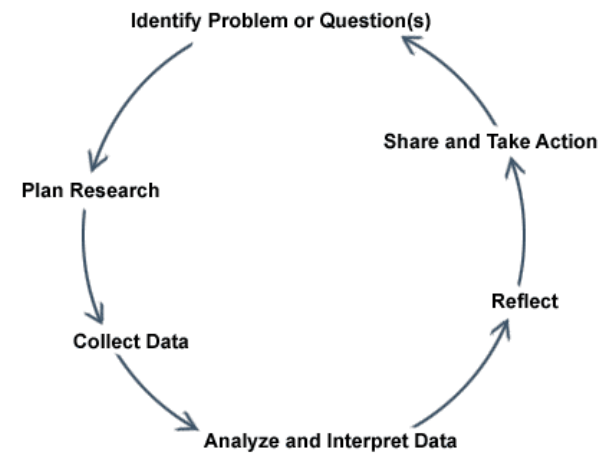

Figure 12. (http://www.drawntoscience.org/educators/action-research/classroom-action-research-1.html)

I sought to gain an understanding of the impact of movement in the classroom. This process required months of discussions with Professors, professionals and peers and hundreds of hours of literature review, lesson planning and reflection, to uncover the 
questions "How can the teaching of movement enhance and strengthen learning in Visual Art Education?" and "How can I design powerful Visual Art Education learning experiences by incorporating movement?" The next process included the design and implementation of the lesson plans in conjunction with reflecting, revising, observing and documenting my work in the classroom. I made changes to respond to the needs of the individual students as well as the entire class to ensure a safe and meaningful environment. The information gathered from my observations as well as my reflections are shared in this study.

\section{Arts-Based Research}

I also use Arts-Based Research as a Methodology. ABRM has been defined as "First, arts-based research is engaged in for a purpose often associated with artistic activity: artsbased research is meant to enhance perspectives pertaining to certain human activities. (educational) and Second, arts-based research is defined by the presence of certain aesthetic qualities or design elements that infuse the inquiry process and the research "text"” (Barone, T. \& Eisner, E., p. 95). I wanted to see if movement would enhance the art-making process. This methodology also allows a "much less conventional" (p. 96) approach for the researcher. Within reason, I did not confine the students' reactions or responses. I did not, as Quantitative methodology assumes, take myself out of the equation. Goddard states, "The only thing that increased student achievement was the effectiveness of the teacher" (as cited in Mendler, 2012, p. 2). I have strongly believed that positive mentors/teachers encourage their students to forge their own educational paths.

I believe that in order to continue learning in your area(s) of interest and pursuit, you must immerse yourself in the knowledge of the people who stood before you. Utilizing Arts-based research has allowed me to be an active participant in this study. As a visual learner myself, I consistently experience a "hands-on" approach to my own learning. I 
was able to interact with peers and students, design movement enhanced art lessons, and immerse myself in the experience. My goal is that this thesis offers an approach to help all students to learn, grow and change. My narration describes my observations of movement within the classroom (and the playground) and the essence of what caught my fancy. "What caught your fancy is not as important as the differences between the two lists. What you included and what you left out speaks volumes about how you see the world. ...You will be revealed" (Tharp, 2003, p.51). Movement cannot be quantified into numbers; it must be described as a "physical reality" (p. 98). "Arts-based educational researchers are, more recently, experimenting with nonlinguistic forms of the arts for alternative modes of representing research data" (Barone \& Eisner, p. 101). I was observing movement as a non-linguistic art-form. I have long suspected that movement presents a unique means for enhancing educational perspective. I aim to offer an account of the experience in order to further propagate the awareness of the many benefits that arise through the incorporation of movement into the classroom. Through the use of Artsbased research that focuses on implemented lesson designs that incorporate art and movement, I reflected on "the lived experiences" (p. 97) as well as artwork created.

It is our role, as teachers, and teachers of teachers, to excite students to continue to learn and explore, to filter best practices from all of the information and methods, and to extract the most meaningful components that will enrich learning experiences and lives. "Graham spoke openly about her incorporation of the ideas and images of others: "I am a thief--and I am not ashamed. I steal from the best where it happens to be-Plato, Picasso, Bertram Ross. I am a thief--and I glory in it...I think I know the value of what I steal and treasure it for all time--not as a possession but as a heritage and a legacy" (Gardner, p. 300). I will share with you what I have learned in the hope that it helps our students. 
These are the steps that I used in my research:

1. Refine the research inquiries

2. Review literature on research methodologies

3. Define the approaches best-matched to my inquiries

4. Develop art lesson ideas that incorporate movement and visual art

5. Reflect upon these ideas and refine them

6. Write final art/movement lessons

7. Implement art lessons and keep notes on my teaching of these

8. Reflect on what I learned from these implemented art/movement lessons

9. Offer suggestions based on my implementation and reflection

The next chapter will discuss my process for the development of ideas for art lessons that combine art and movement. 


\section{Chapter 4.}

\section{Initial Planning Process for Movement Enhanced Art Lessons for Elementary and Secondary Art Education}

The initial thesis ideas started last year when I was struck by the lack of motivation I observed during a variety of art classes taught at a local high school. During the planning process, I was researching literature on the subject as well as discussing it with my Advisors, Professors, friends, and my cooperating placement teachers. I began to investigate ideas that would be suitable for the individual students while also respecting the particular classroom environments in which I would be working. I wanted to implement lesson ideas that involved integrating movement into the art classroom.

Originally, there were many ideas I would have liked to incorporate such as:

- Michelle Montierth developed Art Boot Camp in order to incorporate movement into the Principles and Elements of Design. She developed a lesson to show the students the dynamic power of color: She has students make piles of color (mixed media) and then move about the classroom working on a "floor color wheel." Also her lesson on Balance has students use their bodies to make asymmetrical, symmetrical, and radial body sculptures.

(http://etd.lib.umt.edu/theses/available/etd-07082008

152005/unrestricted/Montierth_Michelle_Professionalpaper.pdf)

- Creating wall or hallway murals by incorporating dance and music.

- Teachers already use, to good effect, gallery and museum trips, where students become aware that their bodies are moving through a museum, stopping, observing a work of art. Some teachers have the students air draw from afar over a Master's work or sketch from observation.

- Mandalas and Labyrinths have long been studied in the art room. Students can create an actual Labyrinth inspired by the Chartres Cathedral and go through the 
process of walking through it. It is an intriguing way to integrate history, culture, art, movement and nature.

- Introduce the Indian tradition of Rangoli chalk painting with an outside temporary art instillation.

(http://artsonline2.tki.org.nz/resources/lessons/visarts/rangoli/teach_learn_e.php)

- Visionary Alison Knowles, a member of the Fluxus movement in the 1960's, can inspire a lesson on Earth day. The students can contribute to a community food bank by recreating her historical "Make a Salad" performance. They can make a giant salad for the event and film it as an advocacy piece for the school. (http://www.newyorker.com/online/blogs/culture/2012/04/salad-as-performanceart.html)

- Work on collaborative artmaking using flashlight videos.

- Children could be shown a video exploring Kandinsky and music and then create movement and music-inspired paintings.

- Have students learn the art of shadow puppetry and put on a shadow puppet show.

- Have students put on a theatrical production incorporating theatre, dance, music, set design, costume making, and mask making.

- Mark-making lesson plans that incorporate movement into the art room will range from small gestures such as mark-making, calligraphy, and sign language; to medium range movements such as air drawing, and gesture drawing. Start students with Japanese calligraphy and small movements. The purpose of these introductory movements will be to loosen students up for their work, encouraging and promoting body awareness and self-confidence, while gradually working up to placing large sheets of paper on the wall or floor and corresponding movement gestures to rhythms in a song.

- Incorporate action language and improvisational theatre that promotes movement (Spolin, 1963, p. 152).

- Warm-up/Cool-down sessions. At the beginning of any class period (or during a class, if the teacher feels the students need a break to let off steam so they can 
refocus), students could warm up with movement activities such as seated leg raises, neck, and shoulder, arm and hand rotations; or work on meditation techniques. Standing exercises teach balance and offer many of the same benefits.

- Designing "Workshops" specifically for teachers to encourage movement in their own practice (Aimone, 2009, p. 7).

- At the beginning of my Secondary placement, Dr. Freyermurth suggested I create a mind-map for my possible Secondary lessons. The following image is a scan of the original mapping of ideas:

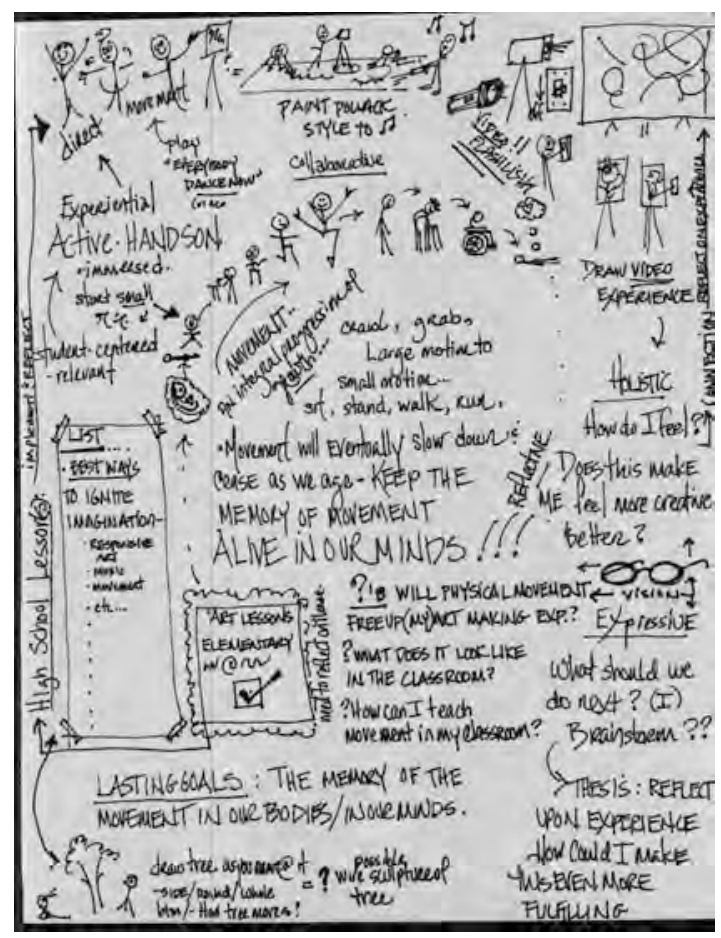

Figure 13. Kathryn B. Adams, Movement Lesson Idea Mind Maps, 2013. 


\section{Chapter 5.}

\section{Implemented Elementary and Secondary Lessons}

In this chapter I will discuss my process of moving from the general ideas I originally explored to the writing of actual art lesson plans. The full art lesson plans can be found in the Appendices of this Thesis. I received Administrative recommendation and approval for all lessons taught. I also made sure that all of the music played and listened to was school and age-appropriate.

Time, logistics, materials, curriculum demands, space, clean-up, cooperating teachers' approval and individual student needs were factors that contributed to my choices for the implemented lessons. Each student teaching placement was approximately 6 weeks long, with an initial 2-week period factored in for observation, leaving 3-4 weeks to teach the lessons. During the initial weeks, I worked closely with my cooperating teachers' to discuss the possible plans. Some ideas such as the large wall mural were eliminated due to time. Although a few iphone video experiments were conducted, the flashlight video lesson required equipment that the schools did not have. In the end, I chose what I thought was best for the students--simply, to move their bodies, listen to music and create art. I simplified and morphed some of the above ideas together. The mark-making lessons were implemented through the use of line, shape, gesture and movement. The Rangoli and Labyrinth lessons morphed into the Outside Playground Exploration. The large "Jackson Pollock" style painting originally eliminated due to the worry that the students and their areas would get too messy, was morphed into more manageable, table-easel sized paintings. In the future, I will implement the above lesson ideas, but they were beyond the limitations of this study. 


\section{Elementary Lessons Reflection}

I taught this entire series of lessons to one first grade class. This helped me monitor the responses of the students over time. I found that, overall, students seemed to enjoy participating in the movement activities. During the beginning stages of each of the lessons there were a few students who questioned what they were "supposed" to be doing. I found that the students who faced the most challenges felt frustrated because it was a very open concept and they were used to a more structured environment. Once they saw the rest of the class participating and enjoying themselves, they become more stimulated, excited, and actively engaged in their artwork. I also found that having the class participate as a whole and then working with teams made these lessons successful. After each lesson, I would reflect on how the children responded to the different activities. I was very excited and pleased at how they interacted with each other and the artwork they produced. During the painting to music lessons using the easels, a student declared to the class "This is the most fun I ever had in Art!" "I'm serious it's so much fun--I'm so excited!" Another student with behavior difficulties and anger management issues was incredibly responsive to the music and visibly actively engaged in moving and painting. You could feel the positive energy in the room and hear the laughter from the students.

I asked my cooperating teacher if I could move the room around and try out a floor lesson. She said "Go for it Kat!" She helped to prepare the room and became our inhouse "D.J." After our initial warm-up, we discussed Abstract Art and the work of Jackson Pollock and Jasper Johns. The students were introduced to the idea of the movement of the lines forming into shapes and large works of art. The floor lesson was a huge success; the students were spinning around on the paper making circular marks around their bodies, learning about shapes and giggling in the process. I witnessed the Elementary School "pep-rally" during which one of the students with autism had severe difficulty with noise and became very claustrophobic. He would put his hands over his ears and scream until his aide took him out of the room. For his particular class, I taught 
the same lesson, changing the creative space to the tabletop. This allowed the student, who would otherwise have been very challenged to get on the floor, to participate with the other students and maintain his personal space. He engaged in the lesson, walked and drew along with the music, and colored in his shapes. I learned it is important to accommodate the special needs of students.

The students met all of the objectives for the lessons. They learned about the importance of movement in the body, and that body movements can be used to inspire the creation of artwork using dynamic lines and shapes. They used body movements to identify feeling and create artwork. They worked collaboratively with their peers utilizing movement, art and music. The students demonstrated the use of a variety of materials including pencils, chalk, and paint, and they gained the experience of moving outdoors to create temporary artwork. I was able to determine this through my observations, assessments and the students' artwork itself. I also feel that they learned these lessons very well because of the integration of movement. When a child states, "This is the best fun I ever had!" it makes me believe that this was a learning experience that will stay with him/her for a very long time.

Future insight into these lessons would be to continually find ways to encourage the students while maintaining a respectable noise level in the classroom, as it seemed their increased comfort with larger movements equated to higher volumes of voices. It is therefore important to have a variety of music on hand to address energy and noise levels. I found that starting with movement exercises such as taking deep breaths while reaching up toward the ceiling, shoulder shrugs and circling the hips, really focused the students and helped prepare them for the next phase of the lesson; while ending with movement exercises, neck rolls, knee bends, and exhaling forward to touch the toes, re-centered them, calmed them down, and prepared them to leave the art room feeling refreshed and ready for their next class. I felt truly blessed to be a part of their creativity and happiness. 
It is important to note that after the extension lesson on shape, I cut the large table and floor drawings into individual sections. I encouraged the students to create individual final compositions, using line, shape and color to create a balanced, unified, cohesive design. Although it is beyond the limits of this study, there are other principles and elements of design that can be addressed though movement in the visual art classroom.

\section{Secondary Lessons Reflection}

The students completed a Pre-assessment "helpful-hints" survey. This information helped me to understand my students' interests and various levels of ability. This tool also helped inform me of their perception of themselves as artists and their "wish list" for learning in this class. I chose Abstract Expressionism as my focus because while observing the students, they seemed to lack motivation, very similar to the other High School students I had previously observed. I had witnessed a wide range of behaviors. Many students shuffled into the classroom, keeping their eyes cast down until they got to their seats, where they would then collapse into their chairs and put their head down on the desk. Students would text on their phones during a class, and become offended if questioned on their behavior. There were students who gave minimal effort, barely drawing a line on a paper to those who blatantly refused to participate in class, yelling, "this is stupid, I'm not doing this." I felt that if I could introduce them to a different method of creating art, Abstract Expressionism, they just might be inspired to be more creative. Through the patient guidance of Professor Robert Collins, I had found inspiration through this method, and I felt the students needed to experience this radically different approach. Many wanted to listen to music, so I incorporated music into the unit planning on Abstract Expressionism.

Using Bloom's Taxonomy \& Webb's Depth of Knowledge questions, class discussions towards higher order thinking were incorporated throughout the unit. Handouts, slide and video presentations were utilized to connect to all levels of students. The handouts can be found in the appendices. The Abstract Expressionism slideshow showcased the art of 
Sonia and Robert Delauney, Wassily Kandinsky, Willem DeKooning, Jackson Pollock, Helen Frankenthaler, and Robert Collins; as well as videos of Kandinsky and Pollock while they were painting. The music slideshow started with a photograph of Mikhail Baryshnikov, an Al Hirschfeld drawing of Jacobs Pillow founder, Ted Shawn, and a clip from the video of Heather Hansen. A quote from Martha Graham preceded the Music segment. The Music compilations began with YouTube videos of Chopin's "Nocturne no.20," followed by Beethoven's "Symphony No. 9," Richard Wagner's "Ride of the Valkyries," and Paul Simon singing "Diamonds on the Soles of her Shoes."

A homework assignment was assigned for the students to engage the interests of each student (they were to identify a song that reflected their emotion or mood) and create their own artwork while listening to the song. Guided peer discussions helped to give students the ability to ask others for information without relaying the questions to the entire class. I also worked individually with the students to assess their progress. Minipresentations by the class and peer sharing were used throughout the unit to encourage participation and aided in students' self-confidence. A constructed response worksheet was utilized as another formative assessment tool. The students had not been given the opportunity to create while standing at an easel prior to my teaching this lesson, so I assembled the table easels that had been in the supply closet. After the initial grumblings of "Can't I sit down?" I noticed a number of smiles and even laughter. The mere act of standing during this lesson promoted the students to move about more freely. I explained to the students that I wanted them to know this was a very safe environment; there was no right or wrong way to create their artwork. I asked the students to participate in some preparatory movement activities. I had them close their eyes and take some nice deep breaths, followed by wrist circles and arm circles. I put the first musical compilation on and asked them to listen and move their bodies to the music, and I had them pretend to be conductors and conduct to an imaginary orchestra. I then asked them to continue to use their body to sway to the music while they painted. I asked them to select materials and colors in reaction to the different compilations and how the music made them feel. As 
the music rhythms increased, the students became even more engaged. Many students started using their fingers to move the paint around the canvas. When "Diamonds on the Soles of her Shoes" was replayed, my cooperating teacher and I started a conga line, the students danced around the room while swaying their hips, kicking up their legs, and waving their paint covered hands around.

These students also learned their objectives for the lessons through kinetic and auditory activities. When asked how they felt about the lesson many students said they finally felt able to express themselves. Through my observations, assessments, and the students statements themselves; I know that the lessons were successful. The students learned that moving does enhance and strengthen the learning experience. The following list contains some excerpts from their exit slips:

- Standing helps

- Free motion

- Letting my whole body move

- It gets rid of stress to paint abstractly/freely

- Use entire body

- Dance is art

- Don't be afraid

- Be creative

- It was charismatic

- Use energy and movement in your pieces

- Being expressive makes the greatest art

In individual and group discussions I asked the students what they would have changed about the lesson. A number of the students wished they could have worked bigger. I then decided that was just the beginning and tried to figure out how to make that happen. 
There was a huge box of cardboard boxes in the supply closet, I asked my cooperating teacher if I could use them for a few lessons, and with the help of one of the functional life skills students, we made 28 standing cardboard easels. They were each about 5' x 3' tall. I used the cardboard flap as the base and leaned them up against the tables. The students were really excited to work at that scale, and I feel they were thankful that I had responded to their suggestions. While listening to their own music compilations, some students shared their ear buds with each other. Some students were listening to soft, classical style music, and their wrist and arm gestures were very slow and flowing. Others who had on hard rock music were making more staccato like movements with their wrists and bopping their heads. They students listened to their music, tapped their feet, swayed their hips, and used their body movements to create dynamic self-expressive artwork. It was a wonderful experience to see the students working together to help each other grow and excel as artists, and to be successful in their interactions with each other. The students struggled a little at first with the concept of loosening up, but overall they had a great time experimenting with incorporating these new ideas, techniques, and media into their art making. It is important to note that after the class discussion on both physical movement and the artwork created through spontaneous, physical movement; I encouraged the students to use their compositions as a springboard. They were to add in any lines, shapes or colors necessary to create a balanced, unified artwork. There are other principles and elements of design that can be addressed through movement in the visual art classroom, but they are beyond the limits of this study. 


\section{Chapter 6.}

\section{Recommendations and Summary}

\section{Recommendations}

In the spring of $2013 \mathrm{I}$ had proposed this project to a few art educators whom I had become familiar with during my placements. They had been reluctant to embrace this topic, because of their feeling that there is already not enough time in the art room to make art, let alone, to move. I was questioned: "Well with all the standardized testing we have to prepare for there is so little time!" Yet, during the months that I had been working on this project, there were countless individuals excited about this proposal: professors, art educators, physical education teachers, photographers, and parents. I challenge the reader to not only implement the ideas set forth in this study, but to persuade others to pursue this path.

Art Education has been part of our U.S. public education since the 1800's (Whitford, 1923, p.109). Numerous school systems are cutting the art and music education programs due to budget issues. Government grant funding for the arts in the United States declined in the past decade; the Los Angeles school district lost $76 \%$ of its total budget in the last 5 years (Flores, 2012, n.p.). This moment is thus a critical time for art education and for America's future. We as art educators are sometimes the "First to know of a situation that a student is going through" (Freyermuth, 2011). Art education is uniquely wellsuited to help children learn to express themselves. "The function of beauty in the education of children is to lead them imperceptibly through sensory experiencing what they will afterward learn to know in its own form as an intelligible principle" (Pink, p. 65). By integrating movement into art education, the students embrace the experience through a sensory experience, which enhances the learning process. 


\section{Summary}

In conclusion, I believe that the teaching of movement does enhance and strengthen learning in visual art education. Through the integration of movement experiences, I have specifically learned and witnessed:

- An overall sense of accomplishment.

- Growth in Self-confidence.

- Positive reflection and peer-sharing

- More enthusiasm.

- Greater participation.

- Less disruption.

- Deeper respect for the teachers and the peers.

- Co-operation with each other

- An increased willingness to help other students.

- The joy of the experience through laughter, smiles, dance and art.

- Less tension.

- Less stress.

- Happiness.

The ideas and research presented only scratch the surface of what could be an entire shift for art education. I believe we should continually focus on the child. As Lowenfeld so eloquently states, "It should not be forgotten that the goal of an art program is to develop the thinking, feeling, and perceiving of each youngster. It is not to produce products. It is not to indoctrinate children into a predetermined way of viewing art. The materials and technical skills follow expression; they do not precede it.”(Lowenfeld \& Brittain, 1987, p. 184).

As Gardner (1993) writes in the preface of Creating Minds, an Anatomy of Creativity Seen Throughout the Lives of Freud, Einstein, Picasso, Stravinsky, Eliot, Graham, and Gandhi, "This book represents both a culmination and a beginning: a culmination in that 
it brings together my lifelong interests in the phenomena of creativity and the particulars of history" (1993, p., xi). This thesis represents both a culmination and a beginning: a culmination in that it brings together my lifelong interests in the phenomena of creativity and the integration of movement. I hope to achieve the same positive results as Cyndie Bellen-Berthézène who wrote, "When I was in graduate school one of my professors made it quite clear that he deemed my belief in the transformative power of art an 'instance of the most puerile romanticism.' In one year of Time I have proven him wrong a hundred times over" (2006, n.p.). There are many wonderful opportunities for further study of this topic; my aim is to encourage educators and students alike to add movement to their classroom and creative practice. This will further their own, as well as their students' creative growth. I will continue to strive for the success of this topic, inspired by a quote from Michael Jordan: "I've missed more than 9000 shots in my career. I've lost almost 300 games. 26 times, I've been trusted to take the winning game shot and missed. I've failed over and over again in my life. And that is why I succeed" (http://www.goodreads.com/author/quotes/16823.Michael_Jordan). The future success of this idea will require continually implementing movement into the classroom setting and advocating the importance of movement as an initiator of and partner to the creative process. 


\section{References}

Aimone, S. (2009). Expressive drawing: A practical guide to freeing the artist within. New York: Sterling Publication.

Auchard. (2003) "One in ten jobs"; "Outsourcing to usurp more U.S. jobs," CNET News.com. Retrieved August 31,2003 from news.CNN.com

Baron-Cohen, S. (2003). The essential difference: The truth about the male and female brain. New York: Basic Books.

Baron, S. \& Damase, J. (1995). Sonia Delaunay: The life of an artist. New York: Henry N. Abrams.

Barone, T. \& Eisner, E. (2012) Arts-based educational research. CA: Sage Publication.

Bellen-Berthézène, C. (2006). Dear Parents. Retrieved May 20, 2013, from http://www.hiartkids.com/index.htm

Binet, A. \& Simon, T. (1873/1973). The development of intelligence in children: The Binet-Simon scale. (Elizabeth Kite, Trans) NY: Arno Press. (Original work published in 1873).

Bright, R. (2013, May 21). Kids who can't sit still: Letting them fidget may keep students focused on learning. Retrieved from http://www.nea.org/tools/47003.htm

Chapman, L.H. (1978). Approaches to art in education. New York: Harcourt Brace Jovanovich.

Chantrell, G., (Eds.). (2002). The Oxford dictionary of word histories, the life stories of over 1,200 words. Oxford, UK: Oxford University Press.

Chen, G. (2009). Is your kinesthetic child getting the right education? Retrieved May 20, 2013, from http://www.publicschoolreview.com/articles/113

Chenfeld, M.B. (1992). Teaching in the "key of life." Educational Leadership. Retrieved April 21, 2013, from http://www.eric.ed.gov/PDFS/ED412199.pdf

Classroom Action Research. (2012). Retrieved April 21, 2013, from

http://www.drawntoscience.org/educators/action-research/classroom-action-research1.html 
Conte, Z. (2001). Schools with spirit: The gift of the arts. L. Lantieri (Ed.). Boston: Beacon Press.

Creating Rangoli. Arts online: TeHapori o Nga Toi. Retrieved March 11, 2014, from http://artsonline2.tki.org.nz/resources/lessons/visarts/rangoli/teach_learn_e.php.

Daniel. (August 9, 2013). Illustrations created with movements of the human body. JazJaz.net. Retrieved February 13, 2014, http://www.jazjaz.net/2013/08/illustrations-created-with-movements-of-thehuman-body.html

Eddy, Dr. M., CMA, RSMT. (2010). Movement in the classroom; Rationales, guidelines, and resources to get schools moving. Retrieved May 20, 2013, from http://wellnesscke.net/k12.htm

Edutopia. (August 29, 2012). Arts Integration for Deeper Learning in Middle School. Retrieved July 20, 2012, from http://www.youtube.co, $\mathrm{m} /$ watch? $=$ cPbKUF 2 zbyw

Edwards, C., Gandidni, L., \& Forman, G. (2012). The hundred languages of children, The Reggio Emilia experience in transformation, Carolyn Edwards, Lella Gandini, George Forman, Santa Barbara: Pragegar/ABC-CLIO, LLC.

Fadiman, C., \& Bernard, A. (2000). Bartlett's book of anecdotes, Boston, New York, London: Little, Brown \& Co.

Feldman, E. (1996). Philosophy of art education. New Jersey: Prentice-Hall, Inc.

Flores, A. (2012). Southern California Cultural Journalism, Artbound: Can schools provide arts education on a tight budget? Retrieved Jan 5, 2013, from http://www.kcet.org/arts/artbound/counties/los-angeles/arts-education-lausd.html

Freyermuth, V.K. (2011) Arte 403/503: Introduction to art education syllabus, (Rhode Island College).

Gardner, H. (1987). Beyond the IQ: education and human development: Developing the spectrum of human intelligences. Harvard Educational Review Vol. 57: 187-196.

Gardner, H. (1990). Art education and human development. Los Angeles, CA: The Getty Center for Education in the Arts.

Gardner, H. (1993). Creating Minds, An anatomy of creativity seen through the lives of Freud, Einstein, Picasso, Stravinsky, Eliot, Graham, and Gandhi. New York: Basic Books. 
Gardner, H. (1993). Multiple intelligences: The theory in practice. New York: Basic Books.

Gardner, H. (1999). Intelligence reframed: Multiple Intelligences for the twenty-first century. New York: Basic Books.

Goddard, J, I. (1994). Better teachers, better schools. San Francisco: Jossey-Bass.

Grosenick, U. (2001). Women artists in the $20^{\text {th }}$ and 21 th century [sic]. Cologne: Taschen.

Hirsch, E. (2002). The demon and the angel, searching for the source of artistic inspiration. Orlando, Florida: Harcourt.

James, J. (4, 2011) The majority of school students sit for too long, new health research suggests. Retrieved February 13, 2014, from http://peninsulapress.com/2011/04/10/high-school-students-sit-for-too-long-newhealth-research-suggests/

Jensen, E. (2001). Arts with the brain in mind. Alexandria, VA: ASCD.

Jordan, M., Michael Jordan Quotes. Goodreads, Inc. Retrieved August 31, 2013 from http://www.goodreads.com/author/quotes/16823.Michael_Jordan

Kessler, R. (2001). Soul of education. Alexandria, VA: ASCD. Retrieved January 5, 2013, from http://www.ascd.org/publications/books/100045/chapters/Introduction.aspx

Key, J. (1997). Qualitative Research: Research design in occupational education. Oklahoma: Oklahoma State University. Retrieved April 20, 2013, from http://www.okstate.edu/ag/agedcm4h/academic/aged5980a/5980/newpage21.htm

Krefting, L. (1991). Rigor in qualitative research: The assessment of trustworthiness. The American Journal of Occupational Therapy, 45(3)

London, P. (2006) Towards a holistic paradigm in art education; Art education: Mind, body, spirit. Visual Arts Research, Vol. 32:16-28.

Lowenfeld, V. \& Brittain, W.L. (1987). Creative and mental growth. Macmillan.

Maxine Greene (2013) Retrieved May 21, 2013, from http://www.maxinegreene.org/ 
McCain, T. (2005). Teaching for tomorrow, teaching content and problem solving skills. Thousand Oaks, California: Corwin press.

Mendler, A. (2012). When teaching gets tough, smart ways to reclaim your game. Alexandria, VA: ASCD.

Montierth, M. (2008) A moving experience: The classroom activities and art camp. Retrieved July 15, 2013, from http://etd.lib.umt.edu/theses/available/etd07082008-152005/unrestricted/Montierth_Michelle_Professionalpaper.pdf

Morais, B. (April 26, 2012). Salad as performance art. The New Yorker. Retrieved September 12, 2013 from http://www.newyorker.com/online/blogs/culture/2012/04/salad-as-performanceart.html

National Art Education Association. (1994). The National visual arts standards. Reston, VA: Retrieved April 20, 2014, from http://www.arteducators.org

North, M. (1961). Composing movement sequences. London: Marion North.

North, M. (1971). Body movement for children; An introduction to movement study and teaching: Boston: Plays, (First edition Great Britain: An Introduction to Movement Study and Teaching, Plays, Inc 1972) Copyright 1971 by Macdonald \& Evans, Ltd.

North, M. (1972). Body movement for children; A composing movement sequences. Boston: Plays, Inc.

Olfman, S. (2003). All work and no play, how educational reforms are harming our preschoolers: CT: Prague Publishers.

Patton, M. (2012). Laureate Education, Inc. Retrieved February 15, 2014, from http://researchcenter.waldenu.edu/Research-Approaches-and-TheoreticalFrameworks.htm

Pilates, J. (1998). Pilates' return to life through contrology. Incline Village, NV: Presentation Dynamics Inc.

Pink, D. L. (2005). A whole new mind, why right brainers will rule the future. New York: Penguin Books. 
Qualitative vs. Quantitative Research. Retrieved April 21, 2013, from http://www.snapsurveys.com/qualitative-quantitative-research/

Rousseau, Jean-Jacques. (1977). Emile. (trans. Barbara Foxley). London: J.M. Dent and Sons.

Saunders, M., Lewis, P. and Thornhill, A. (2007). Research methods for business students. 4th ed. London: Prentice Hall.

Shusterman, R. (2008). Body Consciousness: A philosophy of mindfulness and somaesthetics. Cambridge: Cambridge University Press.

Shusterman, R. (2013). Somaesthetics. In: Soegaard, Mads and Dam, Rikke Friis (eds.), The Encyclopedia of Human-Computer Interaction, 2nd Ed.. Aarhus, Denmark: The Interaction Design Foundation. Retrieved August 20, 2013, from http://www.interaction-design.org/encyclopedia/somaesthetics.html

Sikes, G. \& Gale, K. (2006) Narrative approaches to education research. University of Plymouth. Retrieved August 20, 2013, from http://www.edu.plymouth.ac.uk/resined/narrative/narrativehome.htm

Simpson, J., Delaney, J., Carroll, K., Hamilton, C., Kay, S., Kerlavage, M. \& Olson, J. (1997). Creating Meaning through Art: Teacher as Choice Maker. Upper Saddle River, NJ: Prentice Hall.

Smith, R. (June 16, 2011) Willem deKooning: 'The Figure: Movement and Gesture.' Retrieved June 10, 2013, from http://wwwWILLEM DE KOONING: 'The Figure: Movement and gesture'

Sonia Delaunay. (n.d.). Retrieved June 10, 2013, from http://en.wikipedia.org/wiki/Sonia_Delaunay

Spolin, V. (1963). A Handbook of teaching and directing techniques. Illinois: Northwestern University Press

Stewart, M.G. \& Katter, E. (2008). Rethinking curriculum in art. Worcester, MA: Davis Publications, Inc.

Paul Taylor. (March 17, 2004). "Outsourcing of IT jobs predicted to continue," Financial Times.

Templeton, Rosalyn Anstine; Jensen, Rita A., Can adding movement to learning improve the classroom? Paper presented at the Annual Meeting of the American Educational Research Association, (New York, NY, April 8-12, 1996). 
Tharp, T. (2003). The creative habit. New York: Simon \& Schuster.

Trump, J. (1977). A school for everyone. The National Association of Secondary School Principals, Reston, VA.

Wagner, T. (2012). Creating innovators, the making of young people who will change the world. New York, NY: Scribner.

Waterman, E. (1936). The rhythm book, a manual for teachers of children. New York: A.S. Barnes \& Company.

Whitford, W. The Elementary School Journal. Brief history of art education in the United States. Vol. 24, No. 2 (Oct., 1923), The University of Chicago Press.

Williams, C. (2012). Arte 405/505: Elementary practicum in art education syllabus, (Rhode Island College).

Williams, D. "Unified Studies: A Holistic High School Program.” ERIC Document ED 333552 (1991): 10. 


\section{Appendices}

\section{Revised and Implemented Art Lessons: Movement--Enhanced Elementary Art Lessons}

Rhode Island College

ARTE 562 (MAT) Art Education Program

Date: October 1, 2013

\section{ART LESSON PLAN \\ LESSON 1}

Unit Lesson: What's my line?

By: Kathryn B. Adams

Art Lesson Title: What's my line? Exploring line and gesture drawing through movement.

Grade Level: Grade 1

\section{Learning Objectives:}

Students will:

\section{Objective 1.}

Create lines and shapes through kinesthetic activity. Students will use newsprint and pencils to create their drawings.

NVAS 1: Understanding and applying media, technique, and process.

NVAS 2: Use knowledge of structures and functions.

RI GSE/VAD 1 Artistic Processes: Visual Art and Design is the process of creative problem solving using both traditional and innovative media, tools, techniques, and processes in order to make the imagined visible.

\section{Objective 2 .}

Learn about the importance of movement in the body, and that a range of body movements can be used to inspire the creation of artwork using dynamic lines and shapes.

NVAS 6: Making Connections between visual arts and other disciplines

RI GSE/VAD 2: Perception-All students will observe and experience objects and ideas through a multitude of senses and form a sophisticated, informed response

\section{Objective 3.}

Develop social interaction skills to facilitate better understanding of teamwork and to collaborate with peers for interdisciplinary integration of movement, music and art into curriculum. 
NVAS 3: Choose and evaluate a range of subject matter, symbols and ideas

RI GSE/VAD 5: Integration-All students relate arts knowledge and skills within and across the arts and other content areas.

\section{Assessment:}

1. The student successfully used pencil and paper to demonstrate an understanding of lines and shapes through kinesthetic movement.

2. The student used a range of body movements to create artwork with dynamic lines and shapes.

3. The student worked collaboratively with his her or her peers utilizing movement, art and music

My Personal Stake: The design of this art lesson will inform part of my Master's Thesis work on Body and Kinetic Intelligence: the ability to control one's body movements and to handle objects skillfully.

\section{Discussion / Pre-Assessment:}

Let's walk around the room, how many types of lines can we find? How do we create lines? What are some names of lines?

How could we draw different types of lines?

We are walking and pointing-so we are moving. What are other ways that we move around in class, during P.E., and on the playground? Demonstrate what a straight line looks like while you are walking. How about zigzag, curvy? What's the difference?

Warm-up Activity:(can be performed in Art room, P.E. gym or any classroom-also can be completed as a seated activity)

* Please note that it is advisable to gain permission from Administration and parents for any movement activity. It is also advisable to have students in movement appropriate attire. Teachers should only perform movement activities that are safe and appropriate for the students.

"Let's get warmed up"

Find your personal space

Lie down on the floor-breathe, inhale \& exhale

Reach up to the sky then roll up and touch your toes

Now lift your right leg into the air. Let's use our toes to draw imaginary circles on the ceiling. ( 5 in each direction-then switch to left leg)

Let's kneel on the floor and we will pretend to be a cat-arch your back all the way into the sky and stretch your back.

Now we will imagine we are dogs. Reach our arms out and play bow. Let's turn into elephants, straighten the legs and walk on all fours back and forward.

Sit down reach up and over like a rainbow, twist your waist back and forth, go back into your elephant and roll all the way up and stand. 


\section{Preparation of Room:}

Clipboards, paper, pencils

Divide the class into 2 groups (color-code name tags)

\section{Activity 1:}

A variety of music should be played in timed segments (1-2 minutes each)

Pandora's Kidz Bop Kid's and Radio for Kids Radio are appropriate choices.

Seated group will draw the lines the moving students make.

Red Team-walk in straight lines, Blue Team-Draw the lines the Red team are making. Red Team-walk in zigzag lines, Blue Team-Draw the lines the Red team are making. Red Team-walk in curvy lines, Blue Team-Draw the lines the Red team are making. Now Pick a line in your head and move like that line! Draw all the moving lines. *Switch-Red Team draws while Blue Team demonstrates.

* These activities could escalate into brisk walking, trotting or running-space dependant.

\section{Activity 2:}

A variety of music should be played in timed segments (1-2 minutes each)

Seated group will draw the movement the moving students make.

Variety of moves: Group will run, jump, twirl, dance, reach to sky, hop, skip, jumping jacks, reach to toes, bounce, circle arms, hop on one foot. Switch

\section{Activity 3:}

Still using teams: Students will demonstrate favorite sports movements. Students will "Freeze" into a pose while other team draws them. (1 minute). Switch teams.

\section{Exemplar Artwork:}

Van Gough, 1888. Harvest, the Plain of La Crau

Hiroshige, 1797. Great Bridge of Buddahn Shower at Atake

Closure: Class discussion on the class activities.

Teacher and students engage in breathing and Calming movements. *If possible relaxing music playing softly in background. Lying down, seated or standing exercises. Circle arms overhead inhale, reach arms out to sides and down exhale (3-5 x's)

\section{Resources for Art Content and Interdisciplinary Information:}

Eddy, Dr. M., CMA, RSMT. (2010). Movement in the classroom; Rationales, guidelines, and resources to get schools moving. Retrieved May 20, 2013, from $\mathrm{http}: / /$ wellnesscke.net/k12.htm

Jensen, E. (2001). Arts with the brain in mind. Alexandria, VA: ASCD.

Images search, Yahoo. http://images.search.yahoo.com 
About.com, Art History. http://arthistory.about.com

Pandora. http://www.pandora.com/ 


\section{Assessment:}

What's my line? By: Kathryn B. Adams

Exploring line and gesture drawing through movement.

\section{Name: \\ Date:}

(Circle one)

1. The student demonstrated an understanding of lines and shapes through kinesthetic movement using pencil and paper.
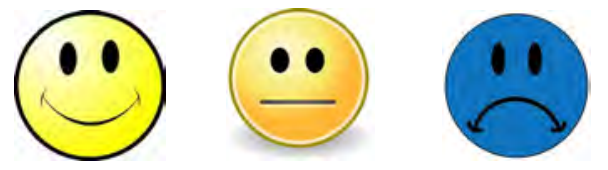

2. The student used a range of body movements to create artwork with dynamic lines and shapes.
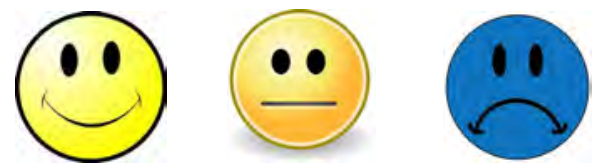

3. The student worked collaboratively with his/her peers utilizing movement, art and music.
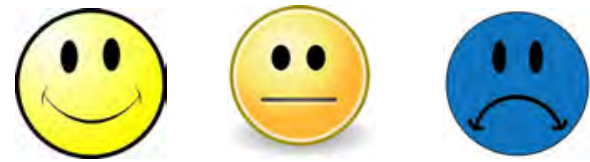
Rhode Island College

Date: October 1, 2013

ARTE 562 (MAT) Art Education Program

\section{ART LESSON PLAN \\ LESSON 2}

Unit Lesson: What's my line?

By: Kathryn B. Adams

Art Lesson Title: What's my line? Outside Playground Exploration

Grade Level: Grade 1

Learning Objectives:

Students will:

\section{Objective 1.}

Explore the material of chalk and the experience of moving outdoors to create temporary artwork.

NVAS 1: Understanding and applying media, technique, and process.

RI GSE/VAD 1 Artistic Processes: Visual Art and Design is the process of creative problem solving using both traditional and innovative media, tools, techniques, and processes in order to make the imagined visible.

\section{Objective 2.}

Identify some aspects about how they are feeling. Students will learn about the variety of ways they can explore feelings through a range of body movements. These explorations will be used to inspire the creation of artwork, using line, shape and form.

NVAS 3: Choose and evaluate a range of subject matter, symbols and ideas

RI GSE/VAD 2: Perception-All students will observe and experience objects and ideas through a

multitude of senses and form a sophisticated, informed response

\section{Objective 3.}

Collaborate with peers in a team setting for the creation of temporary artwork.

NVAS 5: Reflect upon and assess the characteristics and merits of work of others.

RI GSE/VAD 5: Integration-All students relate arts knowledge and skills within and across the arts and other content areas.

\section{Assessment:}

1. The student demonstrated the successful use of chalk and the experience of moving outdoors to create temporary artwork

2. The student used body movements to identify feeling and create artwork. 
3. The student worked collaboratively in a team setting, with his her or her peers utilizing movement and art.

My Personal Stake: The design of this art lesson will inform part of my Master's Thesis work on Body and Kinetic Intelligence: the ability to control one's body movements and to handle objects skillfully.

Pre-Assessment: Class discussion on previous class. Can I have some volunteers to demonstrate how our bodies were designed to move? What types of movements do each of our parts do? What are their actions? Show me what your fingers can do, your arms, legs, shoulders, head, waist.

Demonstration \& Warm-up Activity: Have students perform finger canastas, wrist turning, bending elbows, flapping arms, arm circles, shoulder shrugs, neck rolls, body wiggles, hip twists, knee bends, ankle rolls. Use your whole body reach your arms up to the sky and reach down to the toes.

Between Activities: Have students relocate to another area of playground while running, hopping, skipping or jumping.

Materials Needed: Jumbo multi-colored sidewalk chalk

Discussion: Temporary Artwork

Activity 1: Each student given jumbo piece of chalk. Break the class into teams and groups

Group 1: Have students sit down and draw a square to the side of them-Draw the moves you are seeing!

\section{Demonstration:}

Choose a student to walk at a very brisk pace (a slow run) around the playground -the rest of the class is to trace their movements with their fingers-invisibly drawing in the air (teacher demonstrates). Choose another student to do the same-the rest of the class is to use their fingers and their arms to invisibly trace their movements (teacher demonstrates) Repeat with adding bending knees and swaying bodies.

Group 2: *Have students walk and draw while you are MOVING! Straight lines, curvy lines, zigzag lines. Switch

Activity 2: Class discussion about feelings, If you were feeling really happy, what would you look like? If you were feeling really sad, how would that look? (Teacher and students demonstrate). What if you were really hot or cold? 
Class discussion of Tracing Rules:

1) All poses are by yourself. Create your personal bubble.

2) All poses are appropriate for school.

3) All poses have safety first in mind.

4) All tracing is one hands width away from body.

Now one member from each team is going to get into a pose on the pavement of how they are feeling. Other team member will trace entire pose. When complete discuss with peer the pose and draw the name of the feeling in the pose.

Switch places.

\section{Activity 3:}

As a group students will demonstrate favorite sports movements. Teacher will have students line up against wall-arms outstretched, fingertips barely touching. Teacher will have every other student step away from wall.

Students against wall will "Freeze" into their movement pose while other classmate draws them. Switch peers.

*This lesson can be taught inside using large rolls of paper and any medium of choice. *This part of lesson taught inside having students find shapes from lines.

\section{Visual Exemplar:}

Philip Evergood, Sunny Side of the Street, Retrieved September 3, 2013, from http://msustudent.com/sunny.html

Closure: Class discussion on the class activities.

Teacher and students engage in breathing and calming movements. *If possible relaxing music playing softly in background. Lying down, seated or standing exercises. Circle arms overhead inhale, reach arms out to sides and down exhale (3-5 x's)

\section{Resources:}

Pilates, J. (1998). Pilates' Return to life through contrology. Incline Village, NV: Presentation Dynamics Inc.

Bellen-Berthézène, C. (2006). Dear Parents. Retrieved May 20, 2013, from http://www.hiartkids.com/index.htm 


\section{Assessment:}

What's my line? By: Kathryn B. Adams

Exploring line and gesture drawing through movement.

Name:

Date:

(Check +/-)

1. The student successfully demonstrated the use of chalk and the experience of moving outdoors to create temporary artwork.

2. The student used a range of body movements to identify feeling and create artwork.

3. The student worked collaboratively in a team setting, with his her or her peers utilizing movement and art. 
Rhode Island College

Date: October 1, 2013

ARTE 562 (MAT) Art Education Program

\section{ART LESSON PLAN \\ LESSON 3}

Unit Lesson: What's my line?

By: Kathryn B. Adams

Art Lesson Title: What's my line? Movement and Music

Grade Level: Grade 1

\section{Learning Objectives:}

Students will:

\section{Objective 1.}

Explore and apply tempera paint to create a variety of expressive lines and marks through kinesthetic activity. Students will listen to music and respond through painting.

NVAS 1: Understanding and applying media, technique, and process.

RI GSE/VAD 1 Artistic Processes: Visual Art and Design is the process of creative problem solving using both traditional and innovative media, tools, techniques, and processes in order to make the imagined visible.

\section{Objective 2.}

Choose colors of paint and use a variety of brush strokes based on their feelings while listening to the music.

NVAS 6: Making Connections between visual arts and other disciplines.

RI GSE/VAD 2: Perception-All students will observe and experience objects and ideas through a multitude of senses and form a sophisticated, informed response

\section{Objective 3.}

Reflect upon their work and the work of their peers

NVAS 5: Reflect upon and assess the characteristics and merits of work of others.

RI GSE/VAD 4 (5-6): Students reflect upon, analyze and evaluate the work of self and others by describing one's own work for creativity, quality of craftsmanship, effective use of basic visual arts and design concepts, and choice of subject matter based on the analysis of exemplar works of art or design

\section{Assessment:}

1. The student responded to music with tempera paint through kinesthetic movements.

2. The student used body movements to create paintings with a variety of color and paint 
stroke choices.

3. The student participated in a peer sharing discussing how movement and listening to music impacted their choices.

My Personal Stake: The design of this art lesson will inform part of my Master's Thesis work on Body and Kinetic Intelligence: the ability to control one's body movements and to handle objects skillfully.

Pre-Assessment: Class discussion on previous class.

\section{Warm-up exercises}

\section{Preparation for teaching:}

Prepare Music Compilation (*Teachers music of choice- I used a series of songs from Music teacher. The students were familiar with Mirroring Movements by L. Williams and Sabre Dance by Aram Khachaturian)

Prepare art room with Easels and Media (Tempera paint, paint brushes, water)

\section{Activity 1:}

Have students work in pairs. One student acts as the "Artist" other as "Muse." "Muse" dances to music while "Artist" captures movement. Switch roles.

\section{Activity 2:}

Students listen to music and dance around the art room to the music.

They then stand in front of their easels and choose colors based on music to paint in response to music.

Have students listen to music first then respond.

Increase listening increments from 30 seconds to 2 minutes.

Change music and increase rhythm-suggest using whole body movements to capture essence of music.

Closure: Class discussion on the class activities.

Teacher and students engage in breathing and calming movements. If possible, relaxing music playing softly in background. Lying down, seated or standing exercises. Circle arms overhead inhale, reach arms out to sides and down exhale (3-5 x's)

Peer sharing: Students walk around room, see peer work and engage in conversation about process. 


\section{Assessment:}

What's my line? By: Kathryn B. Adams

Exploring line and gesture drawing through movement.

Name:

Date:

(Check +/-)

1. The student successfully responded to music with tempera paint through kinesthetic movements.

2. The student used a range of body movements to create paintings with a variety of color and paint stroke choices.

3. The student participated in a peer sharing discussing how movement and listening to music impacted their choices. 


\section{Revised and Implemented Art Lessons: Movement-Enhanced Secondary Art Lessons}

Rhode Island College

ARTE 562 (MAT) Art Education Program

Date: November 5, 2013

\section{ART LESSON PLAN \\ LESSON 1}

Unit Lesson: Movement, Music \& Me: Abstract Expressionism

By: Kathryn B. Adams

Art Lesson Title: Movement, Music \& Me: The History of Abstract Expressionism Art Theme: Students will learn about the history of abstract expressionism.

Overarching Unit Goals: Students will understand that abstraction can be a powerful tool to express movement and feeling.

Lesson Goals: Students will gain beginning appreciation of the Abstract Expressionist movement.

Grades: 9-12 Design \& Drawing I. 50-minute class periods

\section{Art Lesson Objectives:}

Objective 1: Students will watch a presentation and video on Abstract Expressionists and learn about the techniques and processes the Abstract Expressionists used to create their artwork.

NVAS 1: Understanding and applying media, technique, and process. RI GSE/VAD 1 Artistic Processes: Visual Art and Design is the process of creative problem solving using both traditional and innovative media, tools, techniques, and processes in order to make the imagined visible.

Objective 2: Students will discuss and understand the history of Abstract Expressionism.

NVAS 4: Understand the visual arts in relation to history and cultures.

Objective 3: Students will reflect on their learning about the techniques and processes of Abstract Expressionism by completing a handout on the Abstract Expressionist movement.

NVAS 5: Reflect upon and assess the characteristics and merits of work of others. RI GSE/VAD 4 (5-6): Students reflect upon, analyze and evaluate the work of self and others by describing one's own work for creativity, quality of craftsmanship, effective use of basic visual arts and design concepts, and choice of subject matter based on the analysis of exemplar works of art or design 
Pre-assessment(s):

*Students will complete a handout entitled "Music, Movement \& Me-Helpful Hints for Ms. Adams"

\section{Pre-Assessment:}

I will ask students what they know about Abstract Expressionism in writing.

I will keep a checklist of participating students.

\section{Evaluation:}

1. The student will participate in a class discussion about the history of Abstract

Expressionism to demonstrate his or her learning.

2. The students will reflect on the work of the Abstract Expressionists.

3. The students will complete a handout on his/her understanding of Abstract

Expressionism.

\section{Essential Questions:}

Describe the mood of the work.

Identify things about the work that you can see. Name and describe.

Analyze the works of art; are there areas that seem more important than another?

\section{Preparation:}

I will prepare a presentation on Abstract Expressionism

(https://docs.google.com/presentation/d/1RB2dIgkNnbmZMh8bXtXJRiGynsDUwDDjR8 fAp8V_MYc/edit\#slide=id.g245f5dae_03)

Students will watch a presentation on abstract artists including videos of artists' artwork.

\section{Closure and Summative Assessment:}

Students will complete an Assessment Handout.

\section{Exemplar Artists:}

Sonia Delaunay

Robert Delaunay

Kandinsky-Exemplar works and video, Kandinsky drawing, 1926,

http://youtu.be/T8yk1Z1224o

William DeKooning

Jackson Pollock-Exemplar works and video (SHOW CLIP-2:30-2:53), Jackson Pollock 51, http://youtu.be/CrVE-WQBcYQ

Helen Frankenthaler/http://jwa.org/encyclopedia/article/frankenthaler-helen

Robert Collins

\section{Materials and Resources:}

https://docs.google.com/presentation/d/1RB2dIgkNnbmZMh8bXtXJRiGynsDUwDDjR8f Ap8V_MYc/edit\#slide=id.g1223773f9_03

http://mhsartgallerymac.wikispaces.com/Abstract+Expressionisn 


\section{Pre-Assessment:}

Movement, Music \& Me: Abstract Expressionism

By: Kathryn B. Adams

Name

Date

Abstract Expressionism

Have you heard this term before?

What do you think it means?

Who were Abstract Expressionist artists? 


\section{Pre-Assessment:}

Music/Movement \& Me-Helpful Hints for Ms. Adams

Name: Date:

When you make ART on your own, what kind of art do you like best?

On the back of the paper, please draw a quick sketch of your favorite animal.

What would you most like to learn in ART class? Circle the following:

How to draw what I see

Comic Book Art

Drawing from Imagination

Caricature Drawing

Anime

Painting

Mixed Media

Printmaking

Recycled Art

Sculpture

Other-Please Explain:

What are your strengths as an artistic person?

What could I teach you that would be most helpful?

Do you have any other helpful comments?

What are your favorite songs?

What are your favorite hobbies and interests?

What are your favorite movements? (walk/run/bike/hike/dance/karate)?

What are your favorite books?

Is there an artist/actor/musician/sports-person/ whose work you enjoy? 


\section{Assessment:}

Movement, Music \& Me

By: Kathryn B. Adams

Name

Date

These works of Art best exemplify what movement in Art?

List 3 Characteristics from that Movement:

Do you remember the names of the Artists who painted these works? If so please name them.

1.

2.

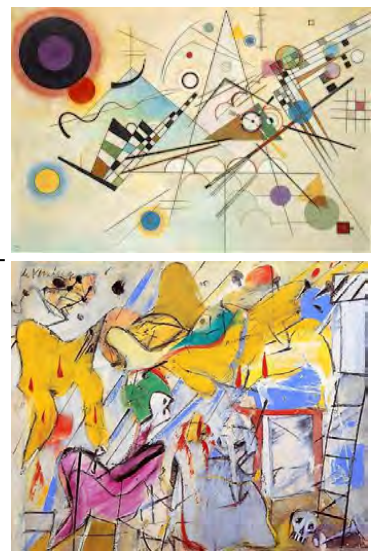

3.

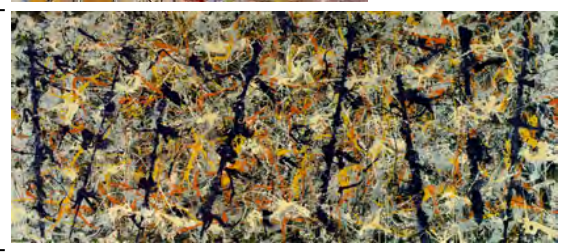


Rhode Island College

Date: November 5, 2013

ARTE 562 (MAT) Art Education Program

ART LESSON UNIT PLAN

LESSON 2

Unit Lesson: Movement, Music \& Me: Abstract Expressionism

By: Kathryn B. Adams

Art Lesson Title: Movement, Music \& Me: Music Responsive Abstract Expressionist Paintings

Overarching Unit Goals: Students will understand that abstraction can be a powerful tool to express and promote movement and feeling.

Lesson Overview: Students will investigate new ways in which to approach the art making process. They will listen to music and learn to respond to the music with the use of body movements. They will explore a variety of art materials to create a series of responsive, abstract expressionist artwork. All music will be age and school appropriate. All lyrics will be pre-screened by teacher for inappropriate content.

Grade Level/Class(s): Design \& Drawing I

Unit: 3-6 class periods; 21 students in the class

Art Lesson Objectives:

Students will:

Objective 1.

Students will learn varied methods of using mixed media in response to music.

NVAS 1: Understanding and applying media, technique, and processes.

RI GSE/VAD 1 Artistic Processes: Visual Art and Design is the process of creative problem solving using both traditional and innovative media, tools, techniques, and processes in order to make the imagined visible.

\section{Objective 2.}

Students will discuss the meaning of their artwork based on their experience of responding to music through movement.

NVAS 3: Choose and evaluate a range of subject matter, symbols, and ideas.

RI GSE/VAD 3 Communication-Visual Art and Design is a vehicle for expression and communication

\section{Objective 3.}

Students will reflect on their learning about the techniques and processes they used in the class. 
NVAS 5:Reflect upon and assess the characteristics of their work and the work of others. RI GSE/VAD 4 (5-6): Students reflect upon, analyze and evaluate the work of self and others by describing one's own work for creativity, quality of craftsmanship, effective use of basic visual arts and design concepts, and choice of subject matter based on the analysis of exemplar works of art or design

\section{Assessment:}

1. The student demonstrated varied mixed media techniques to create artwork in response to music.

2. The student will discuss their body movements to identify feeling and create artwork.

3. The student worked collaboratively in a team setting, with his her or her peers utilizing movement and art.

My Personal Stake: The design of this art lesson will inform part of my Master's Thesis work on Body and Kinetic Intelligence: the ability to control one's body movements and to handle objects skillfully.

\section{Essential Questions:}

In what ways does music affect how you feel? Describe how?

What feelings do you think the musicians trying to express? Describe the feelings to the class.

Choose a way to express the way you interpret this feeling with the materials on the canvas/paper.

\section{Class Discussion:}

Introduction-Question \& Answer:

Go over last class-In what ways do people show expression? How do people express themselves-Give examples:(dance, sing, laugh, gesture)?

There are many ways in which music inspires us.

In what ways does music inspire you?

What inspires you to physically move?

Describe the effects that music has on your life.

Know that this is a non-judgmental, physical and emotional responsive art lesson; consider this a personal investment in yourself.

Demonstrate as we walk around room how you would walk out of a class if you just found out that you "bombed" an exam? (Are you slumped over, shuffling your feet?) 
Now Demonstrate leaving class after you just received a compliment, an $\mathrm{A}+$, or some amazing news.

\author{
Materials: \\ Music Compilation (see below) \\ Sound System \\ Timer \\ Table easels \\ Paper(s) \\ Blick canvas board $16 \times 20$ \\ Black Conte Crayons \\ Color Pastels \\ Faber-Castel Oil Pastels \\ Tempera paint \\ Water Bowls \\ Paintbrushes \\ Baby Wipes
}

\title{
Set-up Room:
}

Set up easels, pre-painted canvas boards, Paintbrushes, Water bowls, and bins with all mediums. Prepare Music Compilations-videos prepared to play https://docs.google.com/presentation/d/1q1sk6fHYrb4UWoydbSbPKojPQ52ZO3NZeH3 Y8yE7OY8/edit\#slide=id.g122728819_023

\section{Activity:}

Discussion: I will describe how there is no right way to respond to this activity. I only ask that you are respectful of your peers, the materials, your surroundings, and yourself to enjoy this experience to help you in your growth as an artist and creative thinker. Music and Movement stimulate your brain.

I am going to play some music. I would like you to listen to the music and the sounds and rhythms. Close your eyes for a moment and pretend you can see what the music looks like. Now open your eyes and imagine you had a paintbrush in your hand and a large canvas in front of you. I want you to "air paint" to the music on your imaginary canvas. I will demonstrate.

Students will stand at their assigned easel.

I will play music from compilations.

First Compilation-Chopin

Students will be asked to pause first and listen to the music (@30 sec.).

Students will be asked to pick up one black conte crayon (from selection of materials at 
each table) and draw what they think and feels the music sounds like in visual lines \& shapes (@1-2 min.)

Students will listen to music and respond with the first material-black conte crayon Place Conte Crayon back on desk.

(Students may choose to rotate the canvas/paper $1 / 4$ turn).

Second Compilation-Beethoven: Pause first listen to the music $(30 \mathrm{sec}$.). Now Choose an oil pastel crayon in the color that you think the music sounds and feels like and draw or what you think the music sounds like in visual lines \& shapes ( $2 \mathrm{~min}$.)

(Students have choice of rotating canvas-rotate $1 / 4$ turn)

Third Compilation-Wagner: Pause first Listen to the music ( $30 \mathrm{sec}$.). Now pick up either 2 Pastel Crayons (from selection of materials at each table) of a color or colors that the music made you think about OR 1 paint color and paintbrush. While listening to the music draw what you think the music sounds like in visual lines \& shapes ( $2 \mathrm{~min}$.)

-DO NOT WORRY ABOUT PAINT MIXING WITH OTHER MEDIUMS-but leave room on your canvas for your lines to breathe.

Place Materials Back on desk.

Pause first. Listen to the music $(30 \mathrm{sec}$.). Now choose either paint or oil crayons in a color that you think the music sounds and paint/draw what you think the music sounds like in visual lines \& shapes. You can change your color when you think you are ready. (2 min.)

Place Paint brushes in Water Bowls on desk and each table moves to the next table over.

\section{Class share and discussions:}

Walk around the room and look at the artwork you have created-for all students to see the works of art their peers have created

\section{Q\&A Response:}

In which painting(s) do you see a particular moment from a song? Do you remember how the song made you think of a particular color, shape, line or gesture?

In looking at the works of can you describe a work(s) that you think best captures the rhythms of the songs? Why?

Go back to your canvas/paper.

I will play an excerpt from the song: "Diamonds on the soles of her shoes" by Paul Simon.

Students will respond with any material from the selection. 
Based on your experience in this class, and in previous classes where you learned about unity, harmony, rhythm, balance, color, line, shape, value, etc... Finalize your painting to create a unified, harmonious, composition that best expresses the experience you had today and the feelings that were evoked while moving and responding to music.

Explain the process of working expressively on the canvas/paper. What is similar or different to what you have experienced before?

\section{Vocabulary:}

Kinesthetic Activity: Mechanical use of the body to express an idea with no regard to aesthetics

Abstract Expressionism/Movement/Unity/Line/Color/Harmony

\section{Closure:}

Fill out exit slip. See below

Place your canvas on the drying rack.

Clean up Materials

\section{Resources for Art Content and Interdisciplinary connections:}

Musee National d'Art Moderne,

http://en.wikipedia.org/wiki/Mus\%C3\%A9e_National_d'Art_Moderne

Willem deKooning, http://www.guggenheim.org/new-york/collections/collectiononline/artwork/992

Jackson Pollock 51,

http://inspirationlog.files.wordpress.com/2009/11/pollock_bluepoles.jpg

Helen Frankenthaler, http://jwa.org/encyclopedia/article/frankenthaler-helen 


\section{Assessment:}

Movement, Music \& Me: Music Responsive Abstract Expressionist Paintings

By: Kathryn B. Adams

Name:

3-2-1 Exit Slip
Class Period:

(3)

Three points

to remember

1.

2.

3.
(2)

Two things you learned

1.

2.
Date:

(1) Any One question you still have

1. questions or comments for Ms. Adams
Name:

3-2-1 Exit Slip
(3)

Three points

to remember

1.

2.

3.
Class Period:

(2)

Two things you learned

1.

2.
Date:

(1) One question you still have

1.
Any questions or comments for Ms. Adams 
Rhode Island College

ARTE 562 (MAT) Art Education Program

Date: November 5, 2013

By: Kathryn B. Adams

\section{ART LESSON UNIT PLAN \\ LESSON 3 (Individual Song Choice)}

Unit Lesson: Movement, Music \& Me: Abstract Expressionism

Art Lesson Title: Movement, Music \& Me: A Journey of discovery through individual song and material choices, artwork, reflection and class sharing.

Overarching Unit/Lesson Goals: Students will understand that abstraction can be a powerful tool to express movement and feeling.

Lesson Overview: Students will investigate new ways in which to approach the art making process. They will listen to music and learn to respond to the music with the use of body movements. They will explore a variety of art materials to create a series of responsive, abstract expressionist artwork. All music will be age and school appropriate. All lyrics will be pre-screened by teacher for inappropriate content.

\section{Art Lesson Objectives:}

Students will:

\section{Objective 1.}

Learn how to identify various feelings in music and select music that best inspires them to bodily move during art making.

NVAS 6: Making Connections between visual arts and other disciplines.

RI GSE/VAD 1 Artistic Processes: Visual Art and Design is the process of creative problem solving using both traditional and innovative media, tools, techniques, and processes in order to make the imagined visible.

\section{Objective 2.}

Understand how a variety of colors and strokes to music and movement can elicit personal expression.

NVAS 3: Choosing and evaluating a range of subject matter, symbols, and ideas.

RI GSE/VAD 3 Communication-Visual Art and Design is a vehicle for expression and communication

\section{Objective 3.}

Discuss the meaning of their artwork based on their experience of responding to music through movement. 
NVAS 5: Reflecting upon and assessing the characteristics and merits of their work and the work of others.

RI GSE/VAD 4 (5-6): Students reflect upon, analyze and evaluate the work of self and others by describing one's own work for creativity, quality of craftsmanship, effective use of basic visual arts and design concepts, and choice of subject matter based on the analysis of exemplar works of art or design

1. The student responded in varied ways to their feelings about music through kinesthetic movements.

2. The student used varied body movements to create paintings with a variety of color and paint stroke choices.

3. The student participated in a peer sharing discussing how movement and listening to music impacted their choices.

Vocabulary:

Expression/ Movement/Harmony/Unity/Shape/Line/Color

\section{Materials:}

Song(s)

Table easels

Wooden Boards

Paper/Canvas

Blick canvas board $16 \times 20$

Black Conte Crayons

Color Pastels

Faber-Castel Oil Pastels

Temper Paint

Water Bowls

Paintbrushes

Baby Wipes

\section{Pre-Assessment:}

Handout/Homework

Students will:

Identify a song or songs that reflects some aspects of how they are feeling at this point in their lives.

Gather information about song and the lyrics. Write personal reflections of why this song expresses how they feel, and a list of words and colors that best describe these feelings. Place Reflection sheet in their journals.

Bring in song(s)/iphone/ear-buds/thumb drive/disc/ listening device.

(Teacher will download songs on Pandora for those who do not have own listening device. Teacher will make sure all music and lyrics are appropriate). 


\section{Activities: \\ Day 1/2: \\ Discussion of Previous Class \\ Discussion of Selected Songs}

Students will listen to their song(s). They will choose from a variety of materials:

conte-crayons, oil crayons, pastels, and paint that reflect their song. They will create a work of art using expression, line, shape, harmony, movement, color and unity to create a work of art that best conveys how the song expresses their feelings.

Students may choose to work on original painting or create new painting into an individual self-expression painting.

Students will view a video Heather Hansen-Empty Gestures, http://vimeo.com/75185969. We will discuss the video.

In-progress sharing of artwork \& peer sharing.

Day 2/3: Students will write a constructed response to this project.

Describe your feelings as you visually responded to the music.

In what ways -if any-has this helped you in this class or other classes?

Explain your choices of materials and composition of your artwork.

If you were to do this project again, would you change any aspect of the process? Please describe.

Day 3/4:

Final Presentation and class sharing

Closure \& Summative Assessment:

In-progress class sharing of artwork(s)

Assessment: Students will write a constructed response to this project.

Final presentation sharing of artwork(s)

\section{Materials:}

Song(s)

Table easels

Blick canvas board 16 × 20

Black Conte Crayons

Color Pastels

Faber-Castel Oil Pastels

Temper Paint

Water Bowls

Paintbrushes

Baby Wipes 


\section{Exemplar Images:}

Heather Hansen, Emptied Gestures, http://vimeo.com/75185969

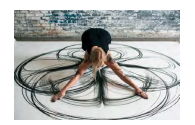

PowerPoint:
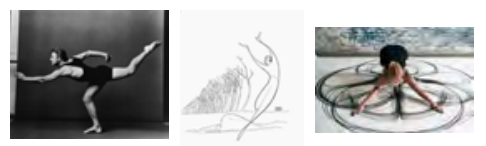

Movement, Music and Art

Slideshow of Exemplar Art:

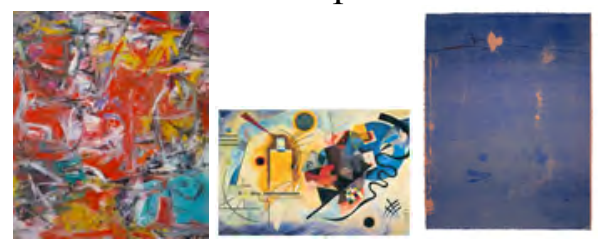

Visual Images:

Franz Marc, Sheep, (1880-1916)

Williem deKooning, Women VI, 1953

Pechstein, Circus

Van Dyke, Mannon Horse

Pablo Picasso, The Lovers

Pablo Picasso, Mother and Child

Degas, Dancers adjusting their slippers

\section{Resources:}

Heather Hansen, Emptied Gestures, http://vimeo.com/75185969

\section{Extension Ideas:}

Have students watch and listen to the Peter Gabriel video, And I'll scratch yours, to discover how musicians have collaborated on each other's work to develop new work. https://petergabriel.com/videos/3kYbmTMbinQ/peter-gabriel-and-ill-scratch-yoursalbum-sampler/ 
Check the boxes you

have

completed
You have researched a song or compilation that best expresses your identity.

You have brought in the lyrics for the song and or title and composer.

You have brought in your listening device.

You have completed your artwork and your constructed response.

Describe your feelings and movements as you visually responded to the music: In class with:

1. Instructor's choice(s) of music

2. While responding to your own music.

EXPLAIN your choice of song/compilation(s) and how you identified with the selection. EXPLAIN your use of color, materials and composition in your final artwork.

In what ways, if any, has this helped you in this class? Has this made any change in your participation or attitude in other classes, or in any event you participated in after the music, movement and art class?

If you were to re-create this project, how would you change any aspect of the process? Please describe.

Did you enjoy the experience? If so, how? If not, why? What did you learn?

Thank you Again! I appreciate all of your responses. . Have an amazing long weekend! Ms.K. Adams Name: Date: 


\section{Modifications for Special learners:}

Both Art Education and the movement of the body are integral components to a child's complete being. It would be promising to integrate this idea into a program for students with Special Needs and physical challenges. I plan on researching this topic in the future, but it goes beyond the bounds of this study. I would like to point out that all lessons were modified for the individual learners. The following factors were addressed:

Modifications were made according to specifications stated in student's IEP, 504 or PLP's.

I reviewed any IEP's and made accommodations as needed.

Adaptive holders were available

PowerPoint presentations and handouts for students who have difficulty organizing and developing written materials were available

For students with learning difficulties I broke down the lessons into smaller steps.

Students were given demonstrations and taught skills necessary to ensure a safe environment for all.

I encouraged the students to work in pairs or in small groups when appropriate.

I asked students with behavior issues to participate in being a helper. 


\section{What's My Line? Exploring line and gesture through movement Inside Gymnasium Exploration Response to Lesson 1 \\ Pencil on Paper}

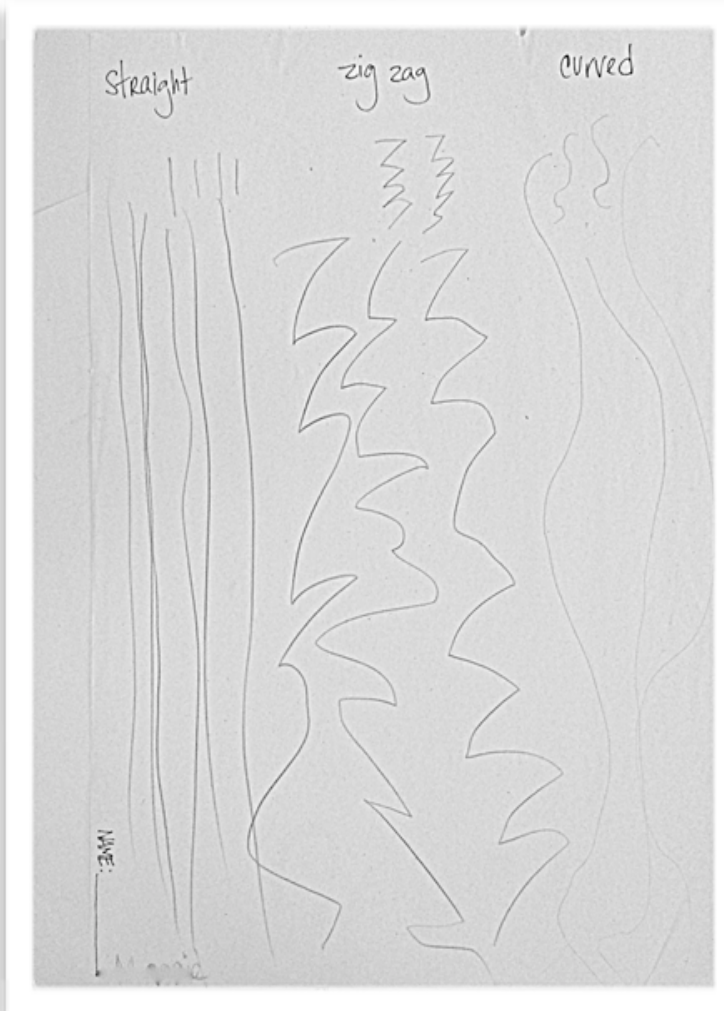

Activity 1: Drawing movement in certain line paths

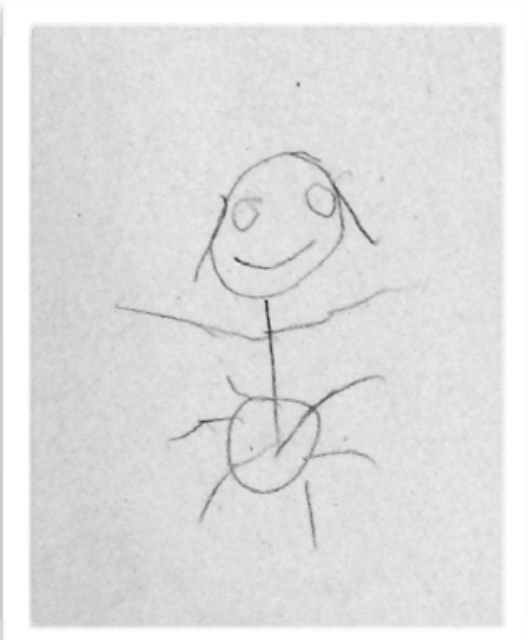

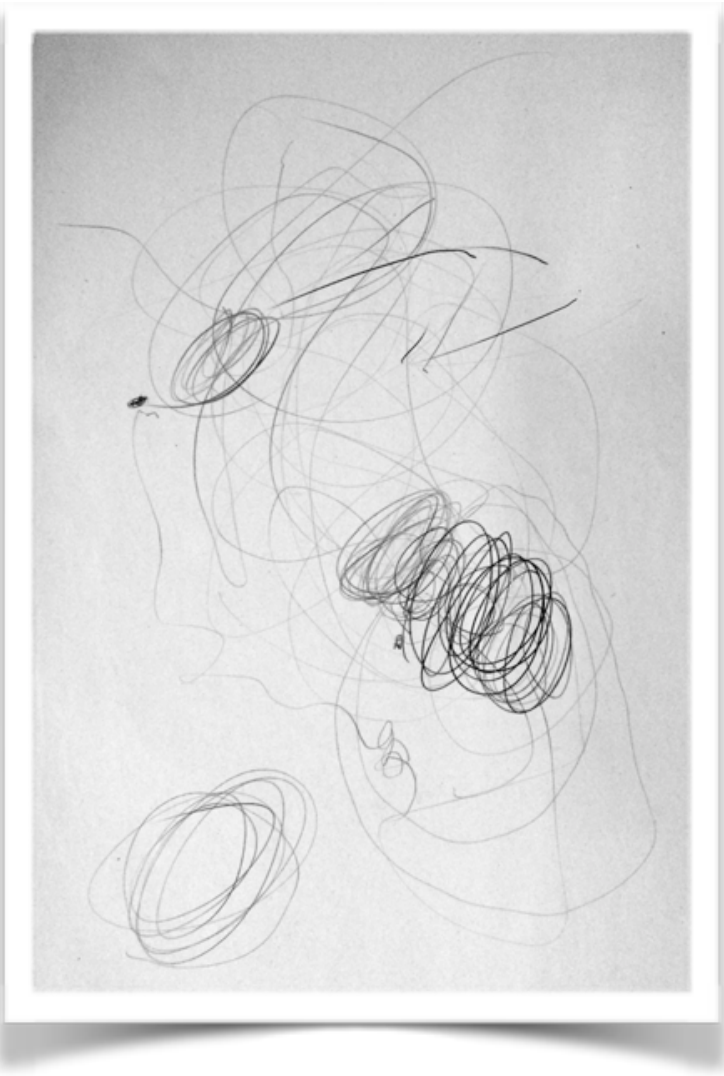

Activity 2: Drawing movement in any line path

Activity 3: Drawing a

favorite sports pose 
What's My Line? Exploring line and gesture through movement Outside Playground Exploration

Response to Lesson 2

Colored Chalk on Blacktop

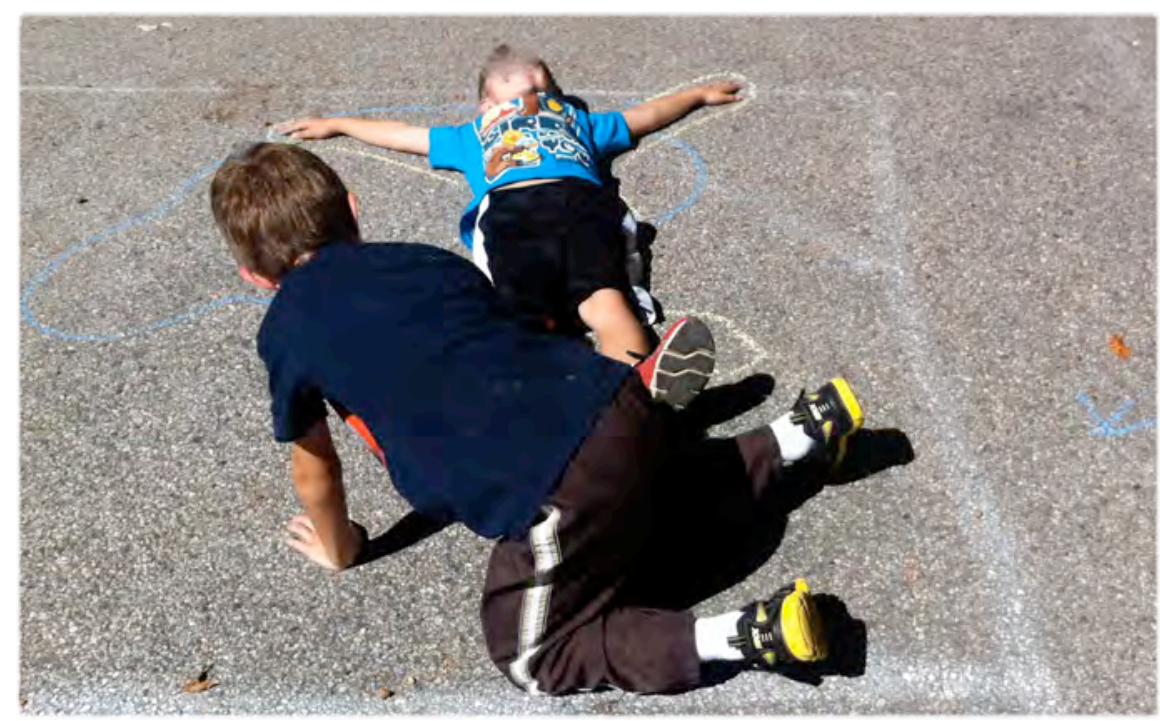

Activity 2: How do you feel? Body Tracing

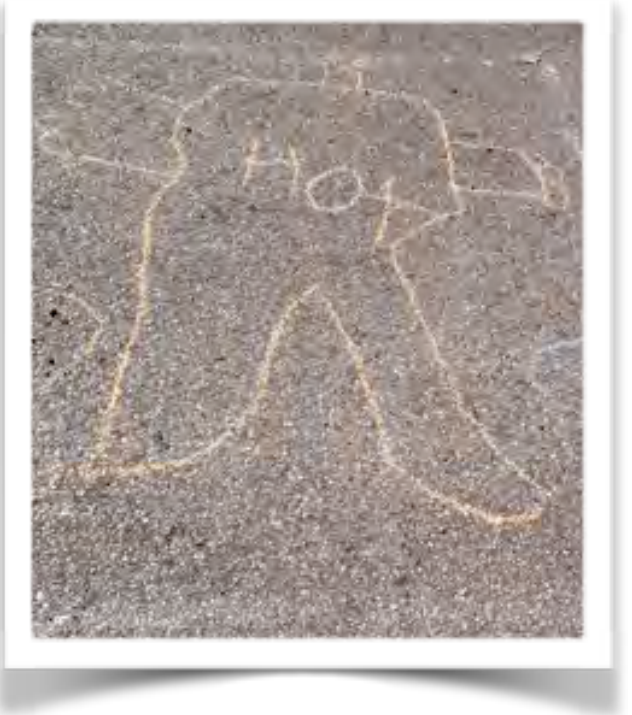

Playground chalk drawing 
What's My Line? Exploring line and gesture through movement Outside Playground Exploration

Response to Lesson 2

Colored Chalk on Brick Wall
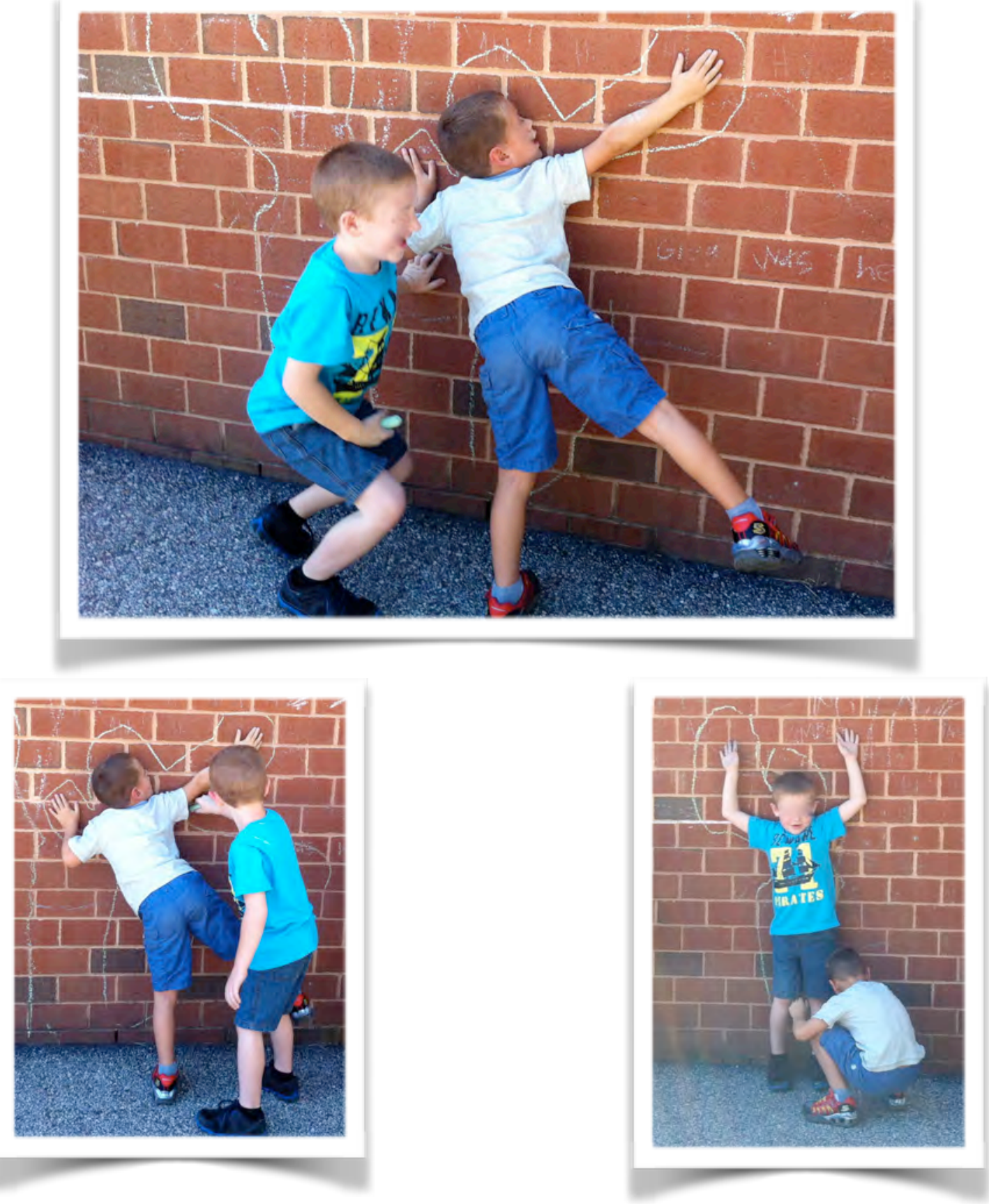

Activity 3: Favorite Movement Pose 


\section{What's my line? Movement and Music \\ Art Room Exploration \\ Response to Lesson 4 \\ Painting to Music Compilation}
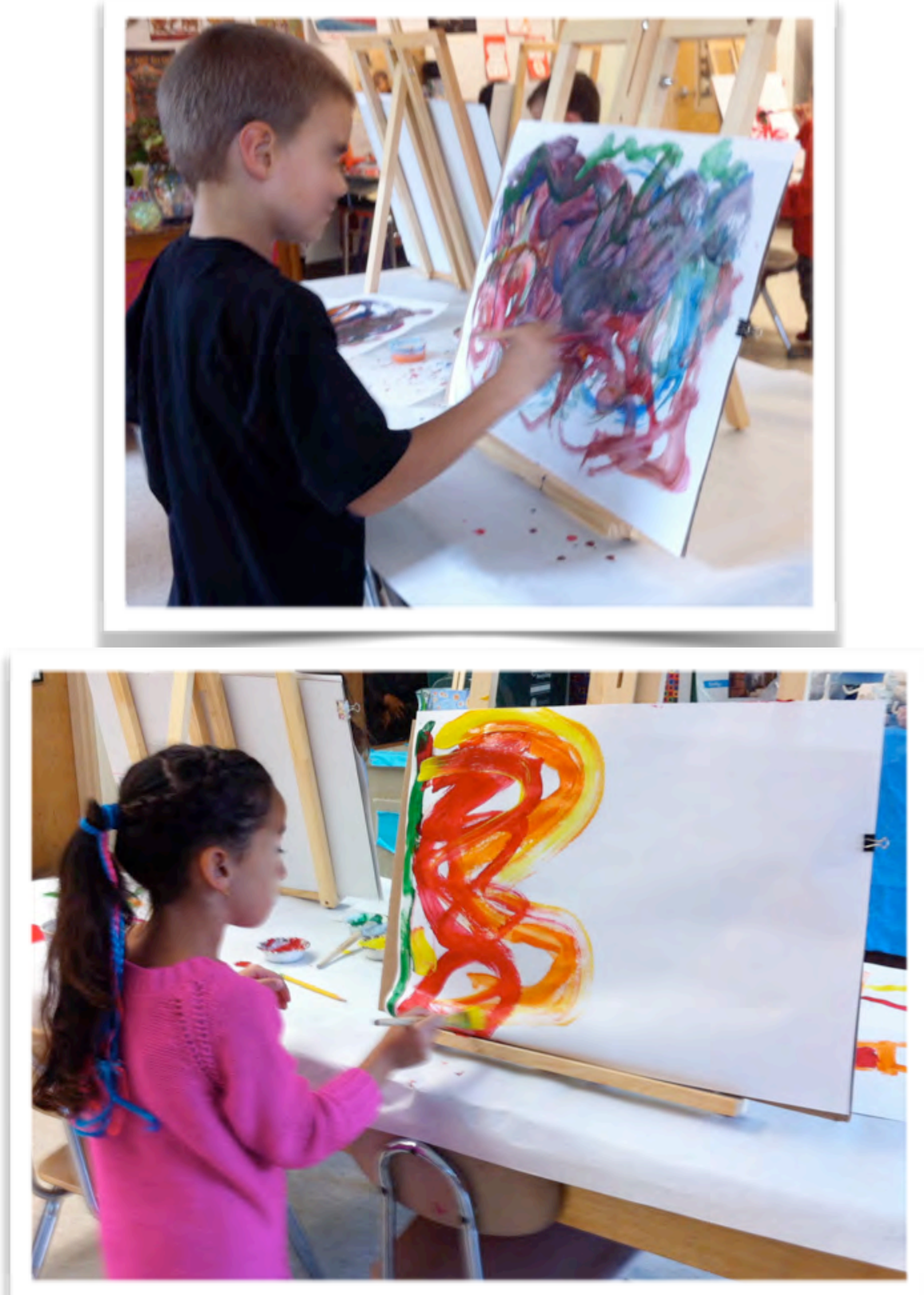

Activity 3: Painting to Movement in Music 
What's my line? Movement and Music

Art Room Exploration

Student Artwork-Lesson 4

Painting to Music Compilation
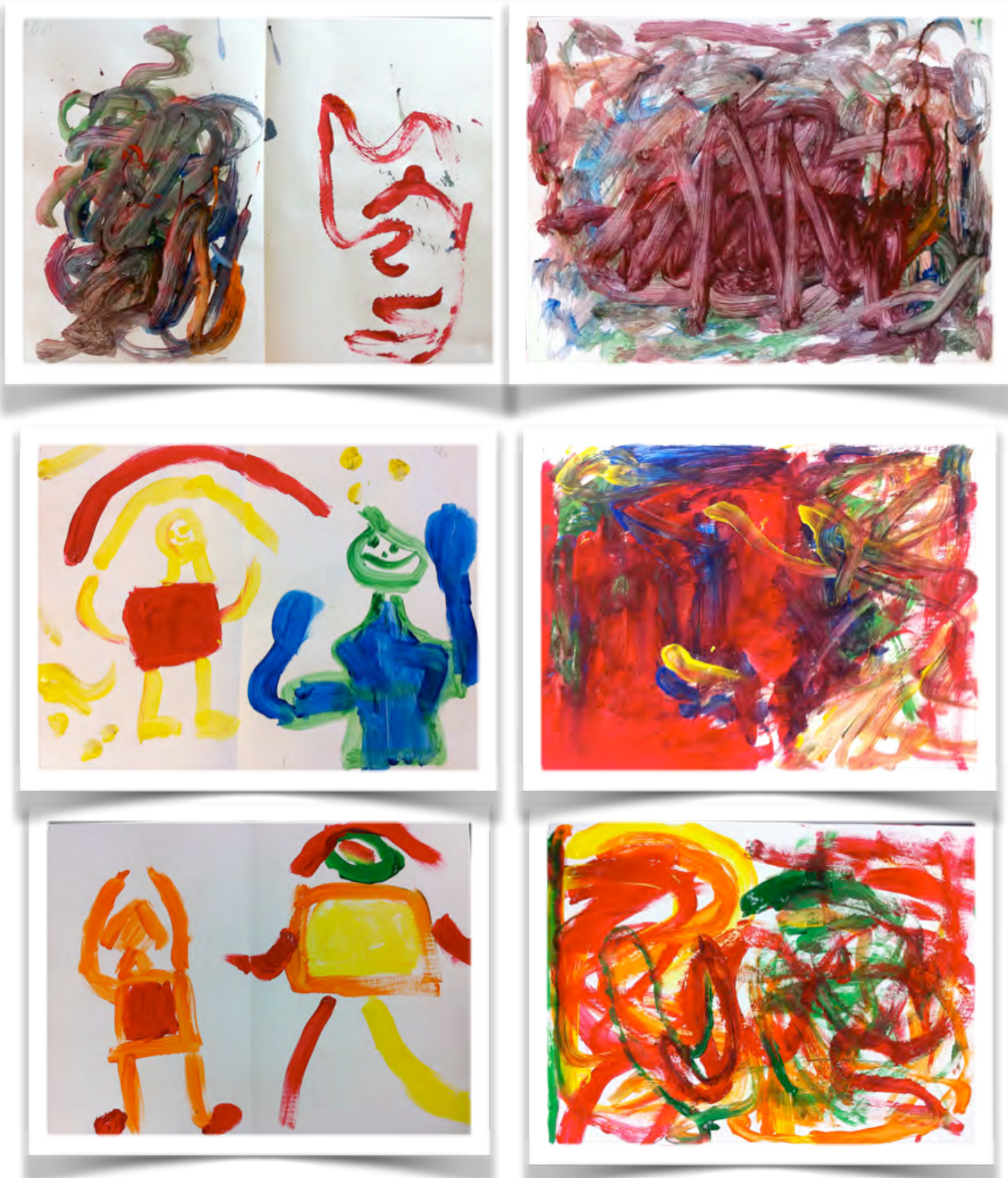

Activity 1 \& 2: Posing and dancing

Activity 3: Painting to movement in music 
What's My Line? Exploring line and gesture through movement Finding Shapes in Lines-Art Room Exploration

Extension Lesson

Marker on paper

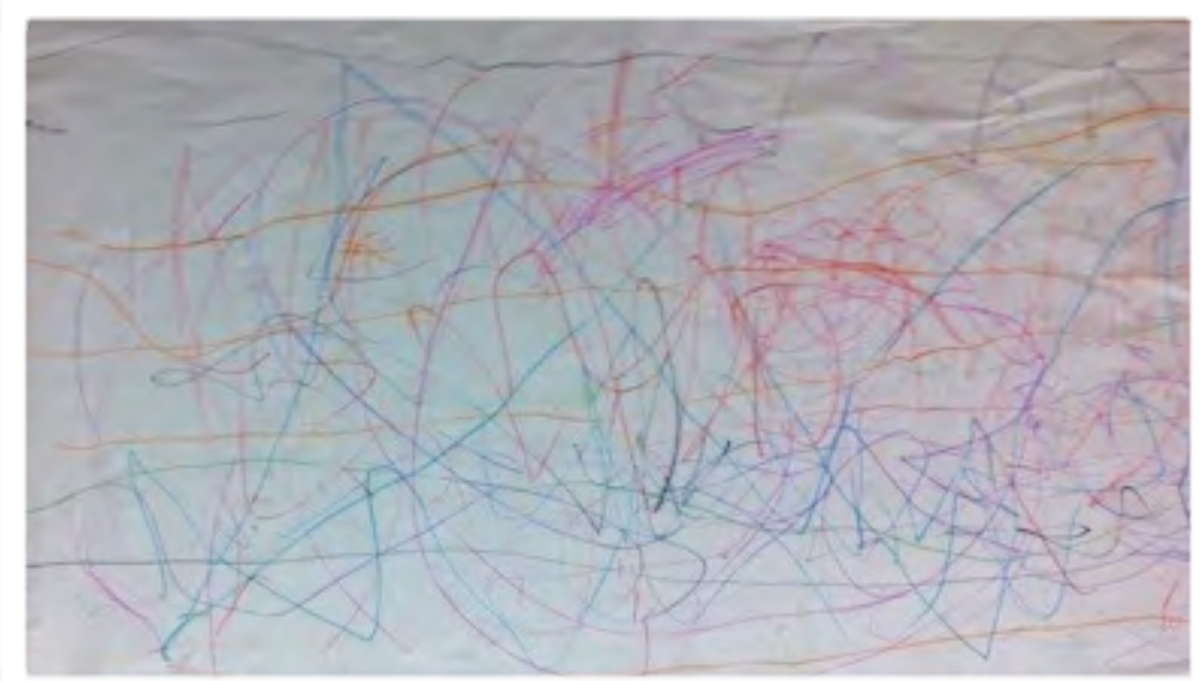

Floor Work

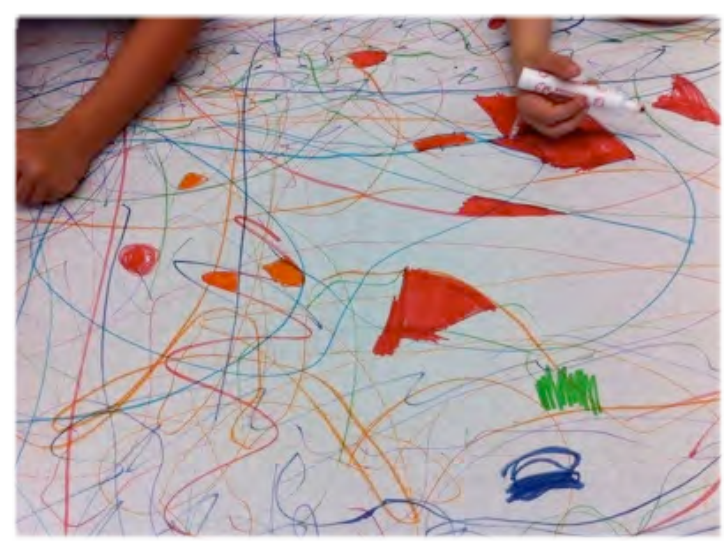

Table Work

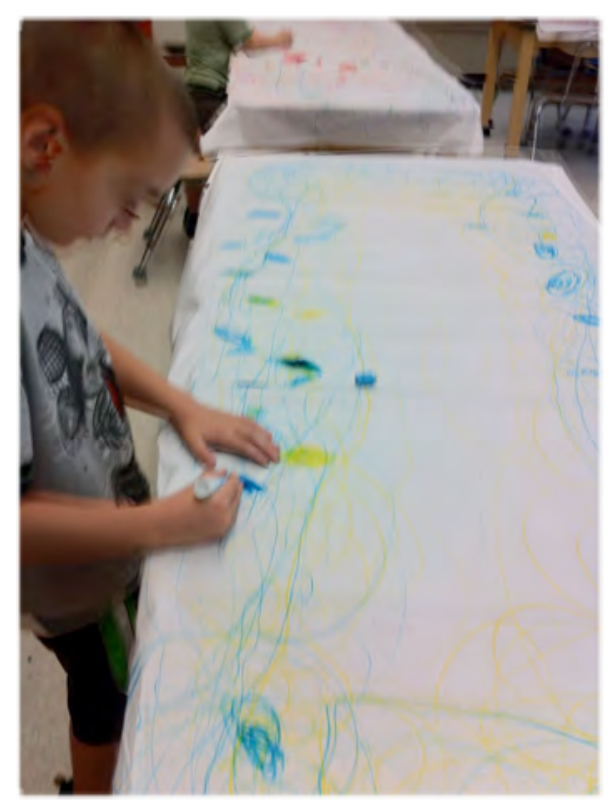




\section{A Special Thank You to my First Graders!} Awesome Job!

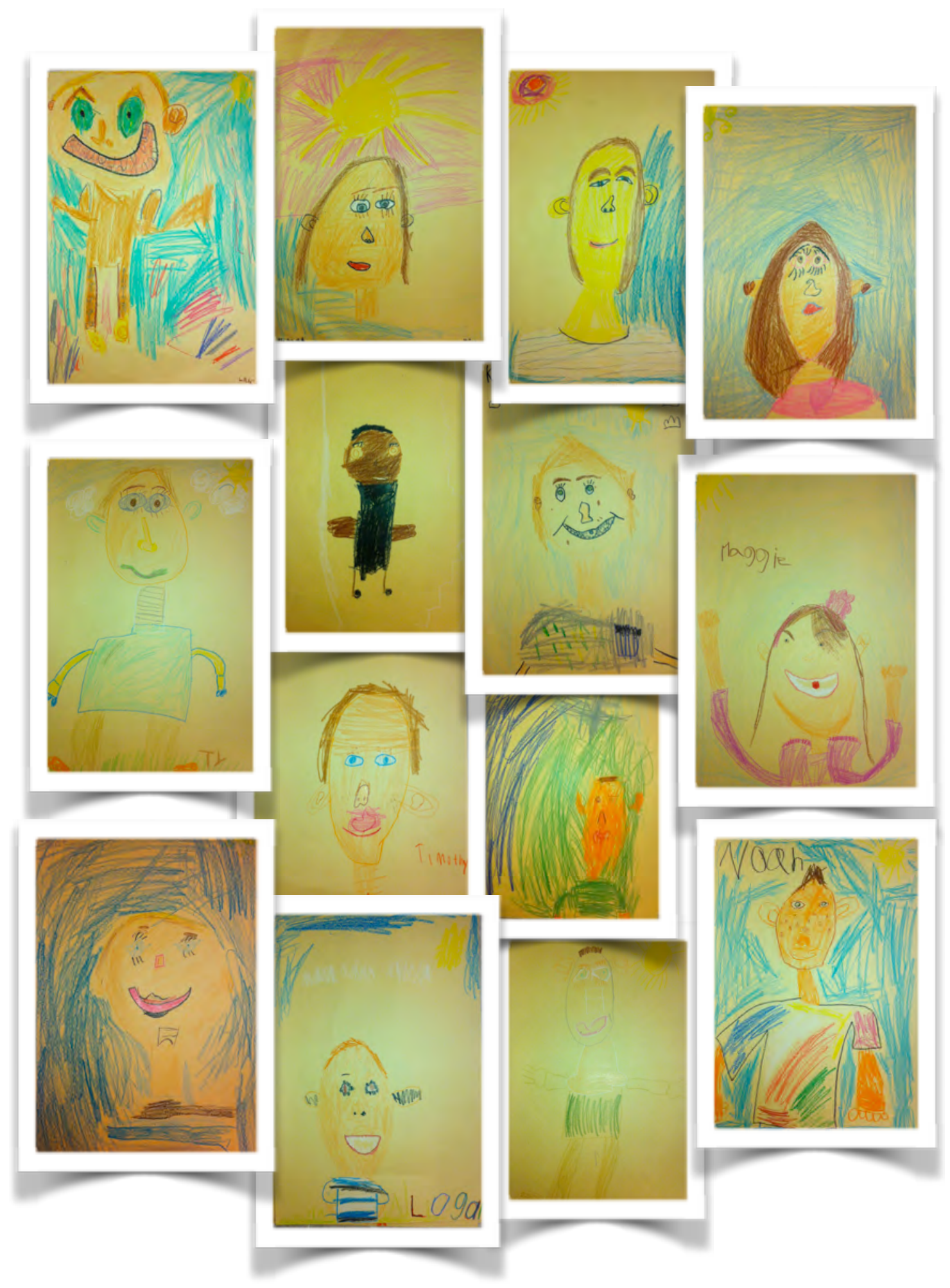


SECONDARY LESSONS

Music, Movement \& Me

Initial Response to Lesson 2

Music:"5th Symphony" by Beethoven

One Choice of Media
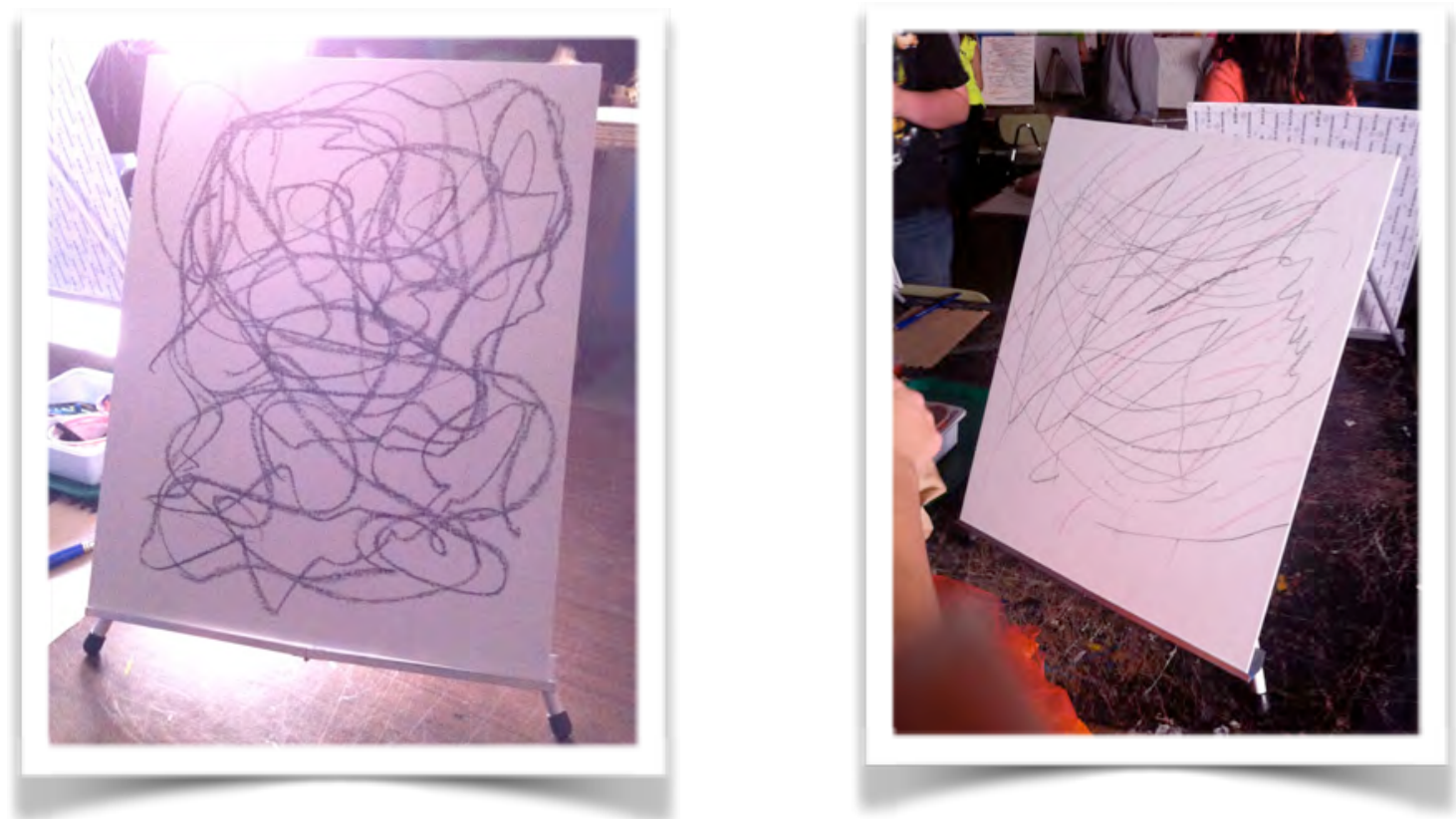

Music, Movement \& Me

Second \& Third Responses to Lesson 2

Music: Richard Wagner

Two Choices of Media

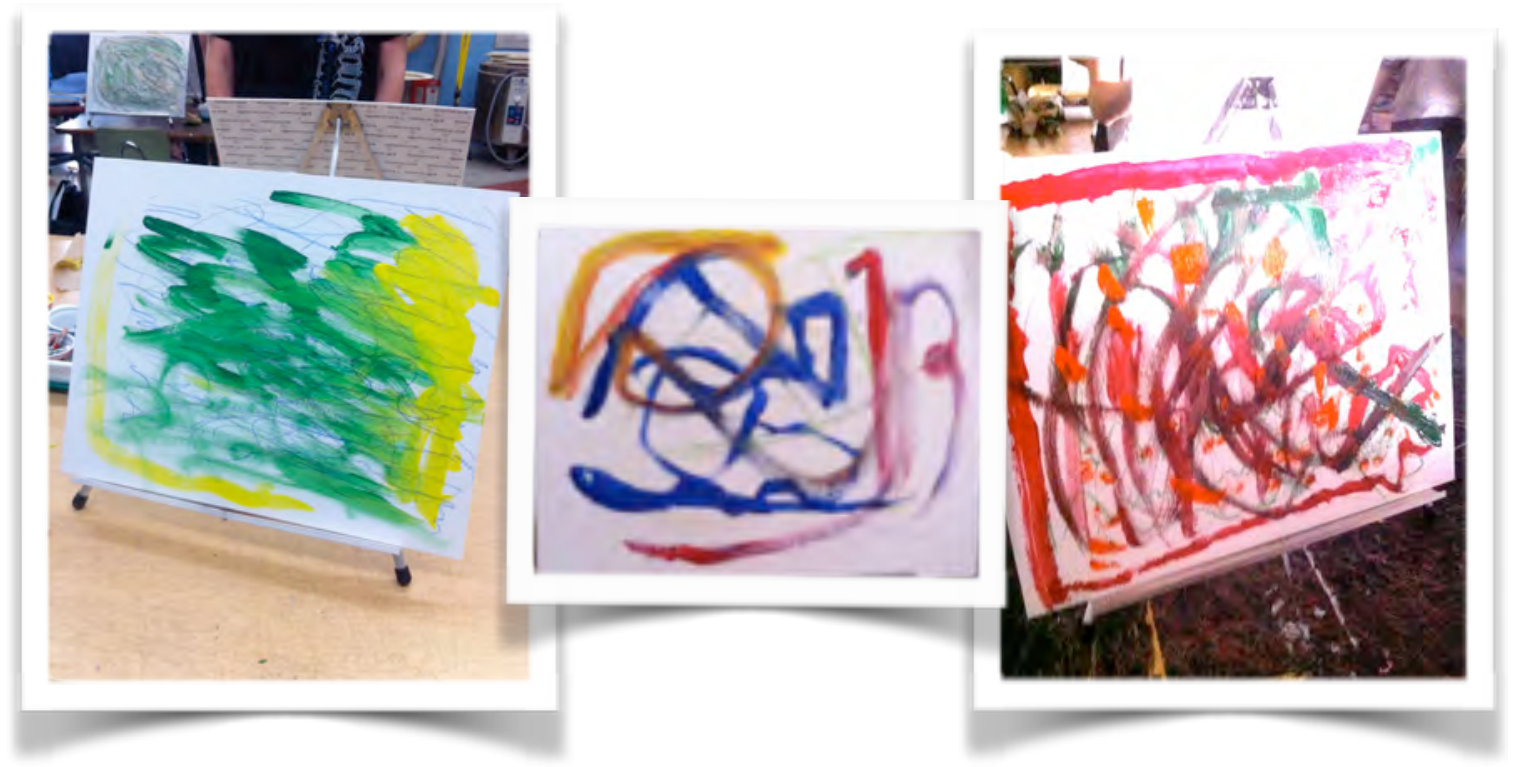


Music, Movement \& Me

Final Responses to Lesson 2

Music: "Diamonds on The Soles of her Shoes"-Paul Simon

Any Choice of Media

Many Students Chose to Use Their Hands
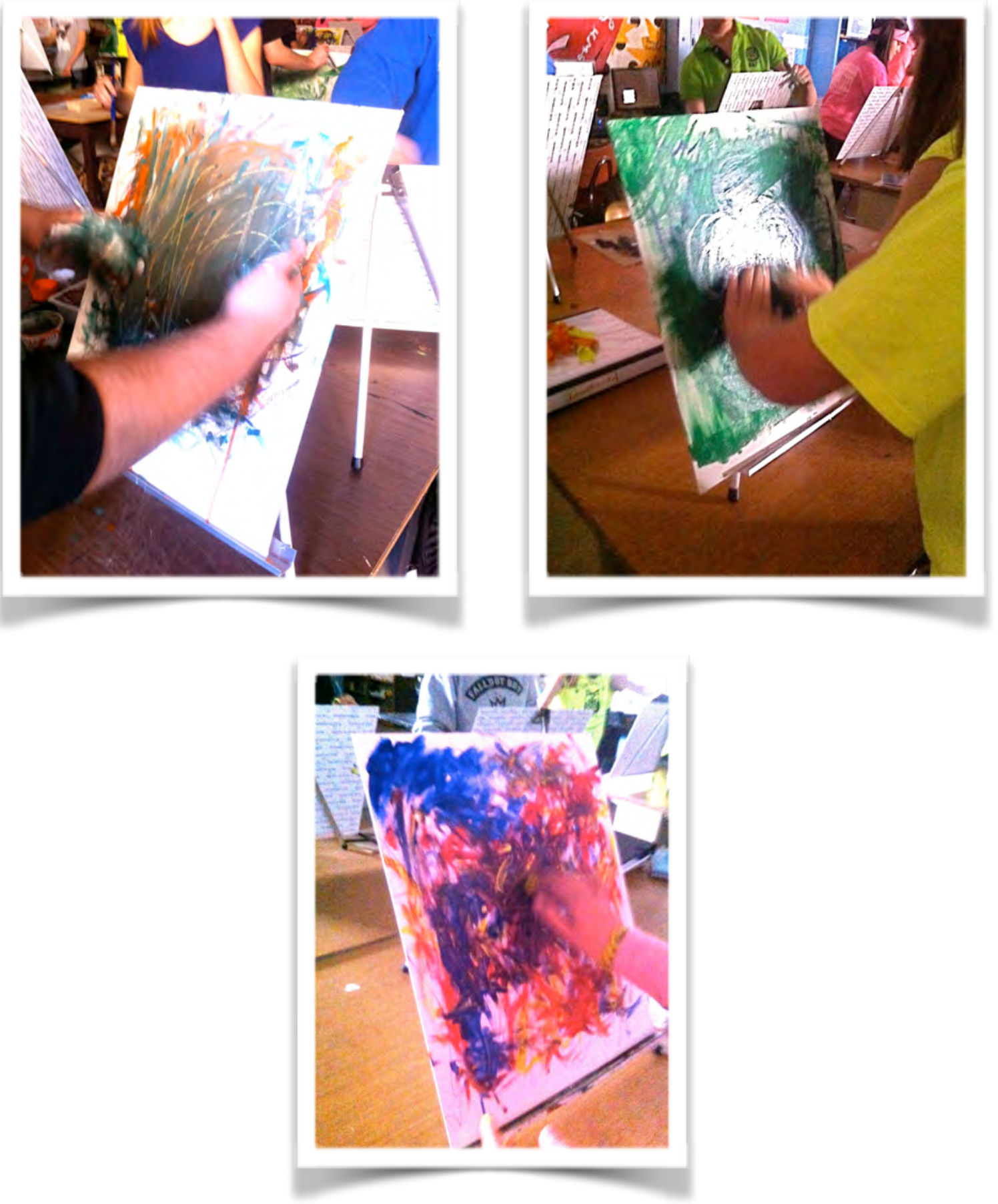


\section{Music, Movement \& Me \\ Student Response to Lesson 2}

This particular had serious difficulty letting go of symbolism throughout the lesson. While listening to her own music compilation, the student seemed to at first draw what was expected of an Abstract Expressionist, not her own Expressions. Then for her final artwork, she painted dots and an anchor.
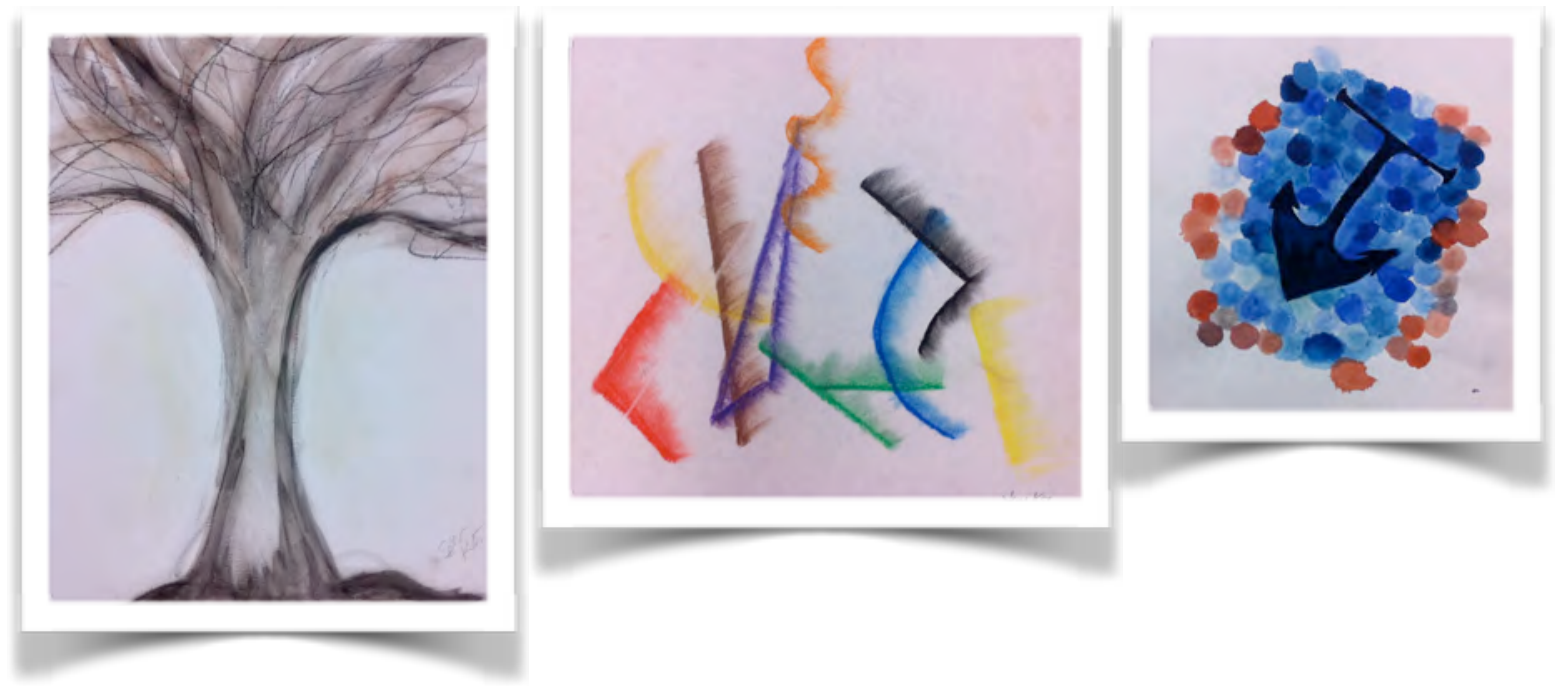

\section{Music, Movement \& Me Special Needs Student Response Lesson 3 (Individual Song Choice)}

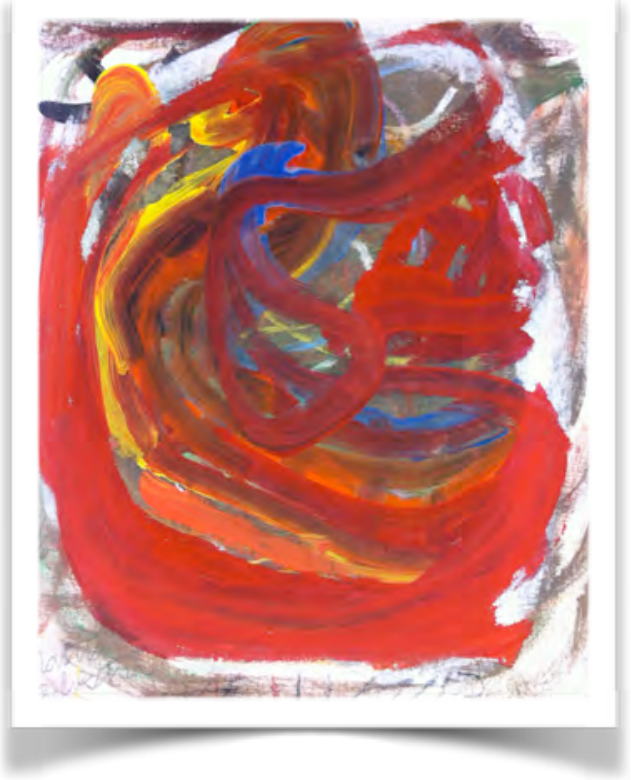

Responding to own compilation of music Student with Special Needs. Student was unsure how to begin, but then actively engaged in the art-making. He was very excited about the process and the art work. 
Music, Movement \& Me

Lesson 3 (Individual Song Choice)

Various Student Artwork
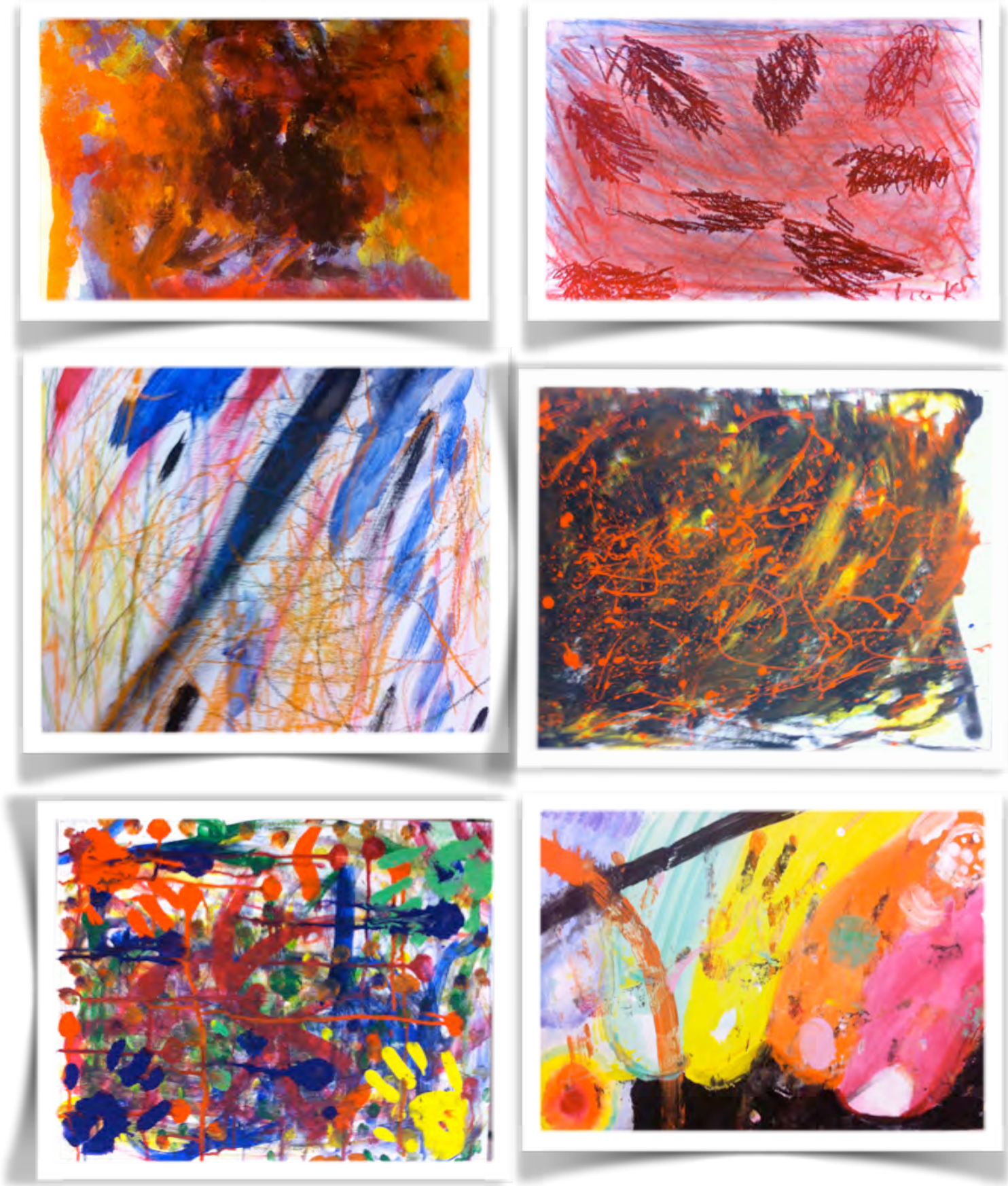
Music, Movement \& Me

Lesson 3 (Individual Song Choice)

Various Works of Art
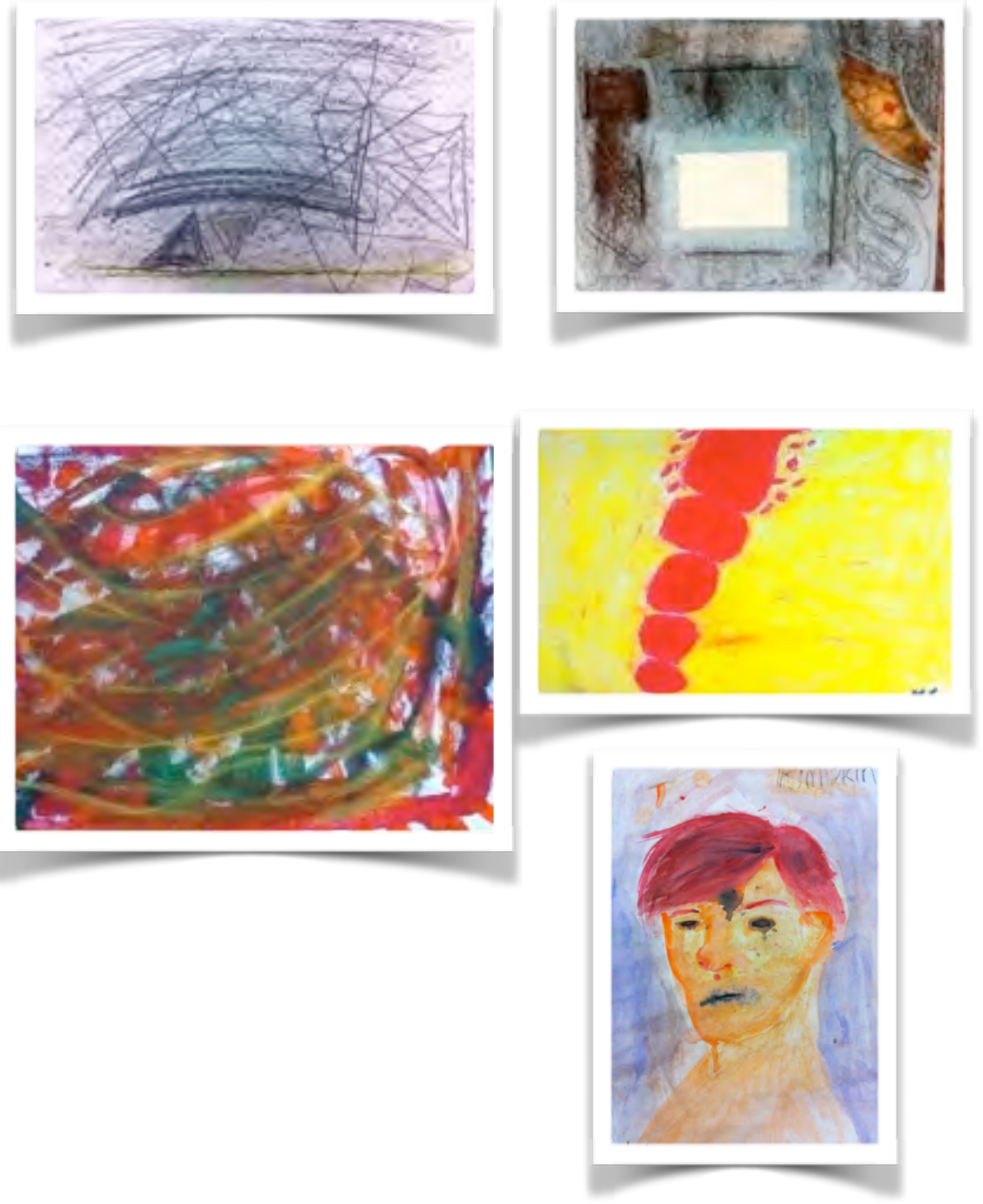
Music, Movement \& Me

Lesson 3 (Individual Song Choice)

Various Works of Art

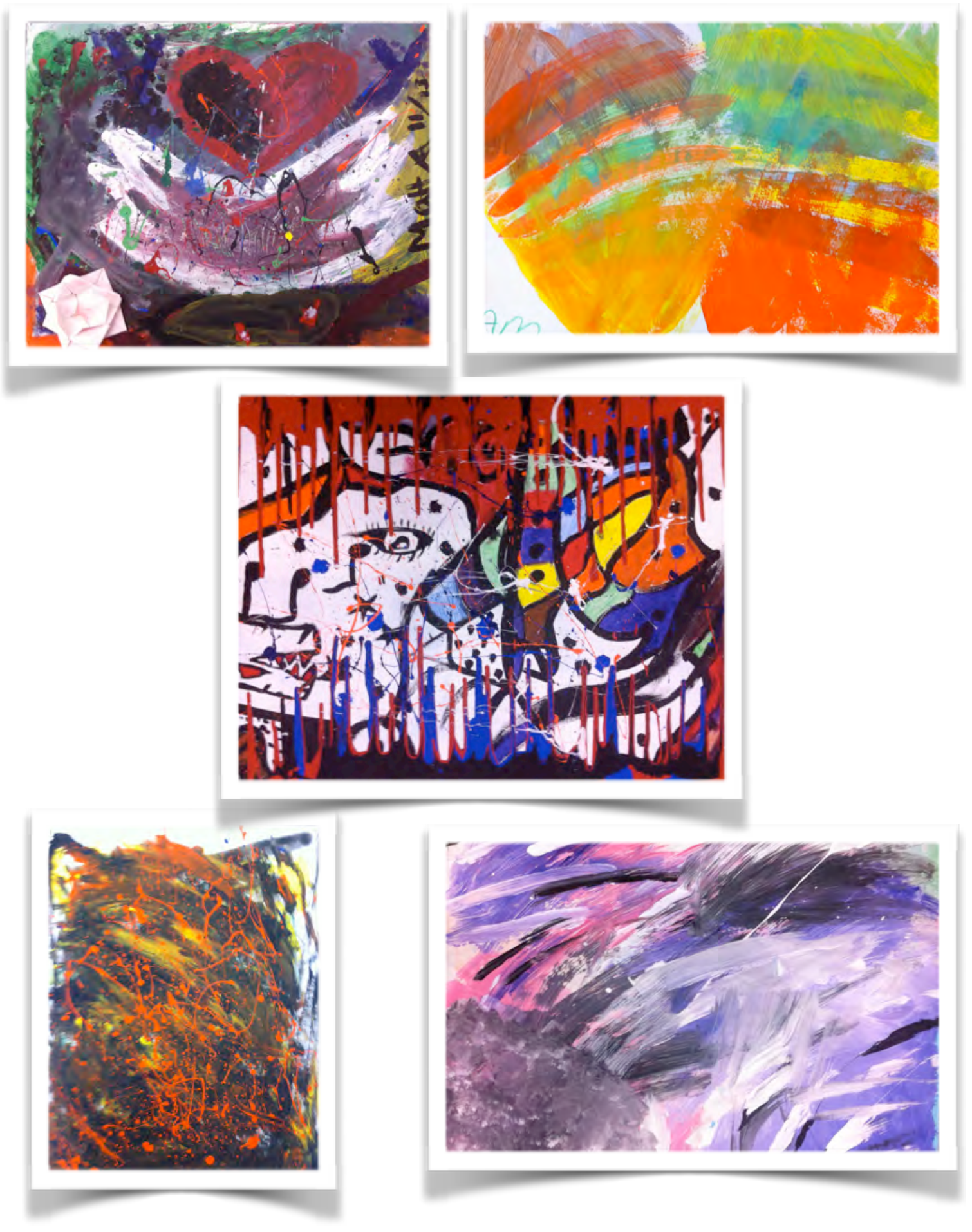

